\title{
WP 03_13
}

\author{
Athina Zervoyianni \\ University of Patras, Greece \\ The Rimini Centre for Economic Analysis (RCEA), Italy
}

Athanasios Anastasiou

University of Patras, Greece

Andreas Anastasiou

Barclays Bank, London, UK

\section{DOES CENTRAL BANK INDEPENDENCE REALLY MATTER? RE-ASSESSING THE ROLE OF THE INDEPENDENCE OF MONETARY POLICYMAKERS IN MACROECONOMIC OUTCOMES}

\footnotetext{
Copyright belongs to the author. Small sections of the text, not exceeding three paragraphs, can be used provided proper acknowledgement is given.
}

The Rimini Centre for Economic Analysis (RCEA) was established in March 2007. RCEA is a private, nonprofit organization dedicated to independent research in Applied and Theoretical Economics and related fields. RCEA organizes seminars and workshops, sponsors a general interest journal The Review of Economic Analysis, and organizes a biennial conference: The Rimini Conference in Economics and Finance (RCEF) . The RCEA has a Canadian branch: The Rimini Centre for Economic Analysis in Canada (RCEACanada). Scientific work contributed by the RCEA Scholars is published in the RCEA Working Papers and Professional Report series.

The views expressed in this paper are those of the authors. No responsibility for them should be attributed to the Rimini Centre for Economic Analysis. 


\title{
Does central bank independence really matter? Re-assessing the role of the independence of monetary policy- makers in macroeconomic outcomes
}

\author{
Athina Zervoyianni, Athanasios Anastasiou ${ }^{* *}$ and Andreas Anastasiou ${ }^{* * *}$
}

December 2012

\begin{abstract}
Using both standard regressions and Markov-Chain Monte-Carlo estimation methods from a Bayesian perspective and a sample of 39 countries for 1981-2006, we re-examine the role of central-bank independence (CBI) in macroeconomic outcomes. Control variables commonly used in the literature are examined together with a number of other variables to which existing studies often give little attention. Our results suggest that lower inflation should be seen as resulting from a broad-range of institutional and structural factors, with CBI failing to play the key role. We also find that central-bank independence has no favourable effect on employment growth, while it increases output volatility following supply-side shocks.
\end{abstract}

\section{Key words:}

Macroeconomic performance; central-bank independence, globalization \& labour markets; Bayesian methods

\section{JEL Classification:} E63, E52, E24, C11

\footnotetext{
"Associate Professor (corresponding author), Department of Economics, University of Patras, Email: athina@upatras.gr

${ }_{* *}^{*}$ Adjunct Lecturer, Department of Economics, University of Patras. Email: A.Anastasiou@ @upatras.gr

**** Research Department, Barclays Bank, London, UK. Email: A.Anastasiou @barclays.uk
} 


\title{
Does central bank independence really matter? Re-assessing the role of the independence of monetary policy-makers in macroeconomic outcomes
}

\begin{abstract}
Using both standard regressions and Markov-Chain Monte-Carlo estimation methods from a Bayesian perspective and a sample of 39 countries for 1981-2006, we re-examine the role of central-bank independence (CBI) in macroeconomic outcomes. Control variables commonly used in the literature are examined together with a number of other variables to which existing studies often give little attention. Our results suggest that lower inflation should be seen as resulting from a broad-range of institutional and structural factors, with CBI failing to play the key role. We also find that central-bank independence has no favourable effect on employment growth, while it increases output volatility following supply-side shocks.
\end{abstract}

\section{Key words:}

Macroeconomic performance, central-bank independence, Bayesian methods

\section{JEL Classification:}

E63, E52, E24, C11 


\section{Introduction}

Central-bank independence (CBI) has attracted considerable attention in the macroeconomics literature since the mid-1990s, a period which has been characterized by significant changes in the central-bank legislation of many countries, not only in Europe but also in other parts of the world. These changes have aimed at increasing the degree of autonomy of monetary policy-makers, giving them authority to focus on the objective of price stability even at the expense of other government goals, including growth and employment. A factor that contributed to the adoption of such legislation was the theory of dynamic inconsistency of optimal plans, according to which elected governments produce an inflation bias when implementing monetary policy (Bergen et. al. (2001); Cukiermnan (2008)).

In the last few years, there has been renewed interest in central-bank independence as a result of three developments. Firstly, the financial crisis of 2007-2008 has made it clear that the independence of central bankers, and the associated pre-commitment argument, is not always enough to assure macroeconomic stability. Secondly, since September 2008, the European Central Bank, whose high level of independence follows from its statute, has not behaved consistently in a way the credibility theory would suggest, effectively abandoning the idea that a loss of reputation for pre-commitment can have detrimental effects. ${ }^{1}$ And, thirdly, a number of recent empirical studies have questioned the robustness of earlier results concerning the association between central-bank independence, on the one hand, and inflation and real output or employment, on the other, by showing their sensitivity to variations in the set of regressors. These developments have raised doubts as to whether CBI really matters.

In this paper we re-examine the practical significance of the independence of monetary policy-makers once other factors that may also help explain macroeconomic outcomes are taken into account. Thus, control variables commonly used in the literature are examined together with a set of other variables to which existing empirical studies often give little attention, including market liberalization and labour-market reform, in an attempt to assess the CBI's relative importance. We focus on a sample consisting of 39 countries, ${ }^{2}$ pooling three periods of roughly equal length, i.e. 1981-1989, 1991-1998 and 1999-2006, which correspond to specific developments in the field of monetary policy. ${ }^{3}$ While for the 1981-1989 period we use the Cukierman, Webb \& Neyapti (1992) (CWN) original scores for central-bank independence for the countries in our sample, for 1991-1998 and 1999-2006 we use updates of the CWN independence index based on the upgraded legislation that has characterized national central banks from 1990 onwards. ${ }^{4}$ In addition to standard regressions, we employ Markov-Chain Monte-Carlo

\footnotetext{
${ }^{1}$ Despite the ECB's apparent high level of independence and the no-bail out clause of the Maastricht Treaty, the European Central Bank has intervened heavily in the markets in the last few years, supplying the EU member-states' commercial banks with extra liquidity and buying up short-term government debt. Indeed, the drop in economic activity in many European countries following the global economic crisis of 2008 and the apparent failure of the pre-commitment argument in periods of financial distress to maintain macroeconomic stability have motivated a discretionary approach by the ECB and a de facto abandoning of the credibility theory as a point of reference for its actions. The Federal Reserve Board has behaved in a similar way, strongly intervening in the financial markets to increase liquidity and lower interest rates.

${ }^{2}$ Australia, Austria, Belgium, Bulgaria, Canada, Cyprus, Czech Republic, Denmark, Deutschland, Estonia, Finland, France, Greece, Hungary, Iceland, Ireland, Israel, Italy, Japan, South Korea, Latvia, Lithuania, Luxembourg, Malta, Mexico, Netherlands, New Zealand, Norway, Poland, Portugal, Romania, Slovakia, Slovenia, Spain, Sweden, Switzerland, Turkey, UK, US.

${ }^{3}$ These three periods correspond, respectively, to: the post-Breton-Woods system of flexible exchange rates; the move towards greater monetary cooperation with managed exchange rates worldwide, on the one hand, and the explicit commitment to coordinate monetary policy in Europe (through the signing of the Maastricht Treaty), on the other; and, the circulation of the euro both in Europe and elsewhere, with the ECB taking over from national monetary authorities.

${ }^{4}$ In the empirical CBI literature a key issue is that of constructing independence indices. A central bank interacts with a number of market participants and this may lead to informal limits of authority with specific groups in the private sector and/or the government. Thus, formally a central bank may be considered highly independent but effectively may not be very independent, something which is more likely to be the case in developing countries. However, as e.g. Cukierman (2008) and Politto \& Guillén (2005) emphasize, effective central-bank independence
} 
(MCMC) methods for estimation from a Bayesian perspective, which are believed to improve results robustness by increasing parameter accuracy and reducing the effect of outlying observations. ${ }^{5}$

The rest of the paper is organized as follows. In Section 2 we discuss the CBI literature. Section 3 describes the data and methodology and also presents our results. Section 4 contains concluding comments.

Our results suggest that lower inflation should be seen as resulting from a broad range of institutional and structural factors, with CBI failing to play the key role. In particular, we find that the point estimates of the CBI coefficients are on average smaller, and less significant, than those of other explanatory variables which are measured on a similar scale, and that the association between central-bank independence and inflation is not robust to the addition of several control variables, including government-sector institutional quality, product market liberalization and changing institutions and productivity levels in the labour markets. At the same time, contrary to what would be expected through increased credibility of commitments to price stability, $\mathrm{CBI}$ is found to have no favourable effect on employment growth once other relevant variable are controlled for. Central-bank independence is also found to reduce the short-run stability of the economy, increasing output volatility following real shocks. This holds even after controlling for institutional quality in the public sector and labour-market variables.

\section{The CBI Literature}

While there has been a large and growing body of literature on central-bank independence since the 1990s, the empirical evidence regarding the role of CBI in macroeconomic outcomes still remains mixed. Much of the early CBI literature suggested that politically independent central banks could achieve lower inflation than CBs in which this independence was absent and indeed at no cost in terms of increased output instability. Grilli, Masciandaro \& Tabellini (1991), for example, who focused on the period 1960-1980 using a sample of 18 industrialized countries, reported a strong negative relationship between the de jure degree of central bank independence and national inflation rates. Alesina \& Summers (1993), extending the analysis of Grilli et al.(1991) as far as the choice of countries and construction of independence indices were concerned, also found a statistically significant inverse association between these two variables. The Grilli-Masciandaro-Tabellini results were confirmed by Cukierman, Webb \& Neyapti (1992), who, examining central-bank independence in 72 economies during the period 1959-1989, found that $\mathrm{CBI}$ was an important determinant of price stability for the group of developed countries in their sample. At the same time, Alesina \& Summers (1993) were unable to provide evidence in support of an adverse effect of CBI on real variables, while De Long \& Summers (1992) and Cukierman et al.(1993), using, respectively, samples of

is a complex matter: in addition to informal limits of authority between the central bank and the government and/or other institutions and pressure groups, it also reflects factors such as the personality of the central-bank's governor and the quality of its high-rank staff. Thus, any attempt to measure effective independence is bound to involve subjective judgments. For this reason, much of the existing CBI literature that focuses on developed countries is based on the independence the legislators meant to grant to national central banks (i.e. legal independence), while studies focusing on developing countries often use the turnover rate of central-bank governors as a more reliable indicator of independence (see Klomp \& De Haan (2010a) for a survey). Of the legal CBI indicators, the Cukierman-Webb-Neyapti index (CWN) is the most widely accepted measure. This index has a broad score range for each factor it measures and many studies have been based on updates of it.

${ }_{5}$ Markov-Chain simulation is a general sampling-based estimation technique that can be used to generate a dependent sample of population parameters of interest, or unobserved vector quantities, from certain distributions of interest (e.g. marginal distributions). More specifically, random draws from such distributions using a (pseudo-) random number generator comprise a way to simulate a sample (multiple observations) from the posterior distribution (these are generally known as Monte-Carle simulations). In cases in which alternative methods do not provide sufficiently accurate results, simulation of the marginal distribution can be achieved by draws from a set of conditional distributions for the unknown parameters of interest. In the case of outlying observations, MCMC fails to result in parameter convergence. 
developed and developing countries, reported evidence of a significantly positive effect of increased CBI on growth. Bleaney (1996), using a sample of 17 OECD countries and taking into account cross-country differences in wage-bargaining structures, arrived at a similar conclusion as he found that independence, while having a favourable effect on inflation, had no adverse influence on unemployment. Analogous results can be found in a number of more recent studies. Carlstrom \& Fuerst (2009), for example, combining legal CBI data with a set of survey-based independence indicators constructed by Fry et.al. (2000), report results implying that about two-thirds of the industrialized countries' improved inflation performance since the 1960 s can be attributed to the increased independence of central bankers. Gutiérrez (2004) finds similar evidence for the Latin American \& Caribbean countries, which suggests that constitutional entrenchment of central bank independence has been significantly associated with falling inflation. Brumm (2000) reports results showing a strong negative relationship between inflation and CBI in a sample of 57 developing countries, using covariance-structure analysis. Crowe \& Meade (2008), using a firstdifference specification, report results indicating that increased central-bank independence has been associated strongly with falling inflation in both the developed and the developing countries since the 1980s, while Brumm \& Krashevski (2003) provide evidence implying that CBI improves the output-inflation trade off associated with disinflation on the basis of disinflation-period data drawn from the OECD countries.

Other studies, however, have reached different conclusions, criticizing the existing literature in a number of directions. Firstly, several authors have questioned the practical relevance of the credibility argument upon which CBI is based, stressing that the independence of central bankers does not automatically resolve the timeinconsistency problem and may prove counter-productive (Bibow (2004); Forder (2001, 2002, 2005); Hayo \& Hefeker (2008)). Secondly, a clear negative relationship between CBI and inflation has failed to emerge in a number of studies after controlling for variables not related to the independence of monetary policy-makers; and, thirdly, the findings of a number of studies have shed doubt on an independent central bank's ability to improve inflation performance with little or no economic cost, or without creating output instability or permanently higher unemployment. Thus, Posen (1995) found that CBI could not help explain cross-country variations in inflation once the financial sector's opposition to inflation was accounted for, using a broad sample of developed and developing countries. Campillo \& Miron (1997) found no sign of a significant link between price stability and central-bank independence in the OECD countries when variables like openness and political stability were included in the regressions. Forder (1998) failed to find a significant link between CBI and national inflation rates after making some reasonable changes to measures of independence widely used in the literature, while Banaian et. al. (1998) were unable to obtain a plausible association with inflation of any of the individual components of the Cukierman et al. (1992) independence index. Moreover, contrary to what the policy credibility argument would suggest, Debelle \& Fisher (1995), Gärtner (1997) and Jordan (1999) provided evidence showing no tendency for the output cost of disinflation to be lower in countries with more independent central banks. Similarly, Posen (1998) found that higher CBI had been associated with significantly greater disinflation costs in the OECD countries during the 1980s and 1990s, even after allowing for non-linearity of the Phillips curve. Fuhrer (1997), using different sub-samples of crosscountry and time-series data, presented results implying significant real costs from CBI in terms of sacrifice ratios with no substantial benefits in terms of inflation, while Cornwall \& Cornwall (1998), in examining unemployment over the cycle, provided evidence suggesting an unfavourable impact of $\mathrm{CBI}$ on employment growth in the short run. 
Evidence in the same direction is reported in a number of more recent empirical studies. Daunfeldt \& De Luna (2008), for example, using a non-parametric regression method to examine the transition process from high to low inflation in the OECD countries, have found no evidence that higher $\mathrm{CBI}$ has contributed to achieving price stability in these countries since the 1990s.Cukierman et al. (2002) have failed to find a robust effect of CBI on the adjustment from high to low inflation of 26 former socialist economies during the 1990s, with their CBI coefficient estimates becoming significant only after an interaction term between independence and internal-price liberalization has been included in their regressions. Neyapti (2001) presents similar results, indicating that financial-sector reform has played a key role in lowering inflation in Eastern-European countries, independently of CBI. Jäcome \& Väzquez (2008), employing data from the Latin American \& Caribbean countries for 1985-2002, find that the association between inflation and central-bank independence is sensitive to the inclusion of a structural-reform index. Siklos (2008), using quantile regressions and CBI indicators based on de jure and de facto central-bank characteristics from more than 100 countries for 1990-2004, also find no strong evidence that higher CBI reduces inflation. In a similar vein, Acemoglu et.al. (2008), using a sample of 52 developed and developing countries covering the period 1975-2003, conclude that there exists no robust general relationship between CBI and inflation, with their results suggesting a statistically significant relationship only in countries with low levels of constraints on political-office holders. ${ }^{6}$ At the same time, Demertzis (2004), extending the Alesina-Gatti (1995) framework of different political parties, has shown that CBI most often comes at a short-run cost to output. Forder (2002) and Demertzis et.al. (2003) have also pointed to significant real costs associated with CBI, once the monetary authorities' interactions with other sovereign policymakers are taken into account. Cukierman \& Lippi (1999, 2001) and Lippi (2003), on the other hand, have stressed the role of the interactions between wage setters and monetary policy-makers, showing that CBI may lead to lower long-run employment levels in economies with inflation-averse unions. Berger et al. (2004) report analogous results, which indicate that CBI may not be the best choice for a country if the outside options for unions, such as unemployment benefits, are fixed in nominal terms, while Hughes-Hallett \& Libich (2012) shows that goal-CBI is Pareto-inferior to explicit inflation targeting and can have negative welfare effects.

In general, a number of recent studies have questioned the interpretation and robustness of earlier findings, pointing to bias in the relation between central bank independence and macroeconomic outcomes due to omitted variables. This conclusion is also supported by the results of Klomp \& De Haan (2010a) in their meta-regression analysis of seventy-nine empirical studies. Indeed, a major problem in much of the empirical CBI literature is that, by regressing independence scores on indicators of macroeconomic performance without adequately controlling for other factors, the possibility that the success of certain economies may have been due to factors other than CBI is

\footnotetext{
${ }^{6}$ Equally controversial evidence can be found in several other studies. For example, in Temple (1998), De Haan \& Kooi (2000), Sturm \& De Haan (2002) and Bouwman et.al (2005), the CBI coefficients in their inflation regressions have proved sensitive to the inclusion of highinflation observations. Thus, Temple (1998), using recursive estimation, has failed to obtain a significant association between CBI and inflation for the OECD countries unless high-inflation economies are excluded from the sample. De Haan \& Kooi (2000) and Sturm \& De Haan (2002), focussing on different samples of developing countries, have been unable to obtain a statistically significant relationship between inflation and the turnover rate of central-bank governors (TOR) unless high-inflation economies are included. Bouwman et.al. (2005) have reached analogous conclusions using quantile regressions and a sample of 57 developing countries, with their estimates indicating a significant association between inflation and TOR only in the higher quantiles. Klomp \& de Haan (2010b) also find no general negative relationship between inflation and TOR, using a broad sample of 100 countries for 1980-2005 and a random-coefficient model, which is similar, in terms of control variables, to that in Campillo \& Miron (1997).
} 
not allowed for. In particular, a higher rate of government-sector institutional effectiveness is likely to have made it possible for certain countries to maintain stable prices, even though their central banks have not been particularly independent. Similarly, the success of several other economies in the sphere of inflation may have been partly due to a higher growth-rate of labour productivity, and, more generally, to changing incentive structures. ${ }^{7} \mathrm{~A}$ related issue is that while CBI is likely to involve significant short-run costs in terms of output or employment, this may not show in the empirical findings due to the activation of counter-active fiscal policy, ${ }^{8}$ or due to other economic and social reforms, which usually accompany the move towards securing the independence of national monetary authorities. For example, since the mid-1990s, many economies have become more globalized through product- and financialmarket liberalization, via the removal of restrictions on current and capital-account transactions (Tsoukis et al. (2003)). Labour-market institutions have also become more flexible in a number of countries, with active labour-market policies being more extensively implemented and employment protection being more liberalized, while at the same time there has been a weakening of trade-union power (Belot \& Van Ours (2004); Baker et al.(2005); Floro \& Pastore (2010); Betcherman (2012)). These developments, by changing the degree of rigidities in product and/or labour markets, may have affected the relative importance of central-bank independence in explaining macroeconomic outcomes. ${ }^{9}$

In this paper we seek to add to the existing literature in two ways. First, we control for variables which may impact on the association between central-bank independence and macroeconomic outcomes but which, either individually or as a group, are often given little attention in existing empirical studies. These variables include improvements in government-sector institutional quality, reform aiming at securing a free product-market environment, and labourmarket conditions. ${ }^{10}$ Second, we check the robustness of our results by using, in addition to standard regressions, Markov-Chain Monte-Carlo (MCMC) methods for estimation from a Bayesian perspective, which increase parameter accuracy and reduce the effect of outlying observations.

\section{Central-bank Independence and Macroeconomic Performance}

\subsection{Evolution of Central-bank Independence}

Graph A.1 below, plots, for the sample of countries we consider, updated (average) legal CBI scores (LCBI) for 1991-1998 and 1999-2006 based on the CWN methodology (Cukierman et al. (1992)), ${ }^{11}$ along with the original

\footnotetext{
${ }^{7}$ Indeed, for a number of countries in our sample, the decline in inflation, as well as other macroeconomic developments, has coincided with a period of wider economic reform aiming at increasing effectiveness in the public sector and at changing incentives in the private sector. Other broadly-based structural-reform policies, aiming at product- and financial-market liberalization, privatization and institutional changes in the labour market, have also been implemented by several countries in our sample since the mid-1990s.

${ }^{8}$ Monetary and fiscal expansions have, at times, been negatively correlated, reflecting attempts by policy-makers to neutralize the effect of exogenous shocks on aggregate demand (Camplillo \& Miron (1997); Acemoglu et.al. (2008)). Such a negative correlation can arise even if the central bank is independent, provided that it is prepared to coordinate policies with the fiscal authorities (Demertzis et.al. (2003)).

${ }^{9}$ An increasing number of studies draw attention to the role of labour-market conditions not only for determining employment outcomes, but also for explaining inflation performance (Nunziata \& Bowdler (2005); Campolmi \& Faia (2011); Thomas \& Zanetti (2009); Abbritti \& Weber (2010)).

${ }^{10}$ For example, Acemoglu et.al. (2008), while examining extensively the role of constraints on political-office holders, do not allow for the impact of market liberalization. The same applies to Growe \& Meade (2008). Cukierman et.al. (2002) control for internal priceliberalization but do not account for the role of public-sector institutional quality. Jäcome \& Väzquez (2008) control for generalized structural reform aimed at increasing product-market liberalization and/or public-sector effectiveness but do not explicitly take into account the effect of changing labour-market institutions and/or labour-productivity levels.

${ }^{11}$ Among the first to construct legal independence indices were Grilli et al. (1991), Cukierman et al. (1992) and Alesina \& Summers (1993). Updates of, and modifications to, these indices have been produced by a number of studies, including Neyapti (2001), Cukierman et al. (2002), Polillo \& Guillén (2005), Arnone et al. (2006) and Crowe \& Meade (2008). Neyapti (2001), including three additional criteria to the CWN codification system, has produced relevant indices for eight Eastern European countries for the early nineties. Cukierman et al. (2002) have
} 
CWN scores or 1981-1989. ${ }^{12}$ These three periods involve changes in central-bank legislation for a number of countries. At the same time, looking at the $L C B I$ scores across the three periods in Graph A.1, it is evident that there has been a significant increase in the average level of central-bank independence since the 1980s. With the gradual implementation of the Maastricht regime, the EU-15 increased their average $L C B I$ score by $28 \%$ between 1981-1989 and 1991-1998. In the 12 new EU member states (NEUMs), LCBI scores showed a mean of 0.50 in 1991-1998. Following the Luxembourg European Council of December 1997, however, all the NEUMs started to implement adjustment policies and these adjustments were accompanied by legislation aiming at securing greater independence of their monetary authorities. As a result, the NEUMs show, as a group, an increase in central-bank independence by 34.5\% between 1991-1998 and 1999-2006, with some of them having reached independence levels in 1999-2006 comparable with those of the EU-15 countries. Several other economies, including Mexico, Iceland and Canada, have also increased their $L C B I$ scores, although some countries, such as Japan, Norway and Korea, still show relatively low central-bank independence levels. Overall, LCBI shows a mean of 0.674 in 1999 -2006 as compared to 0.360 in 1981-1989, which corresponds to an average increase of 87.2 percent.

\section{GRAPH A.1 Central bank independence: Pooled sample, 1981-1989, 1991-1998 \&1999-2006}

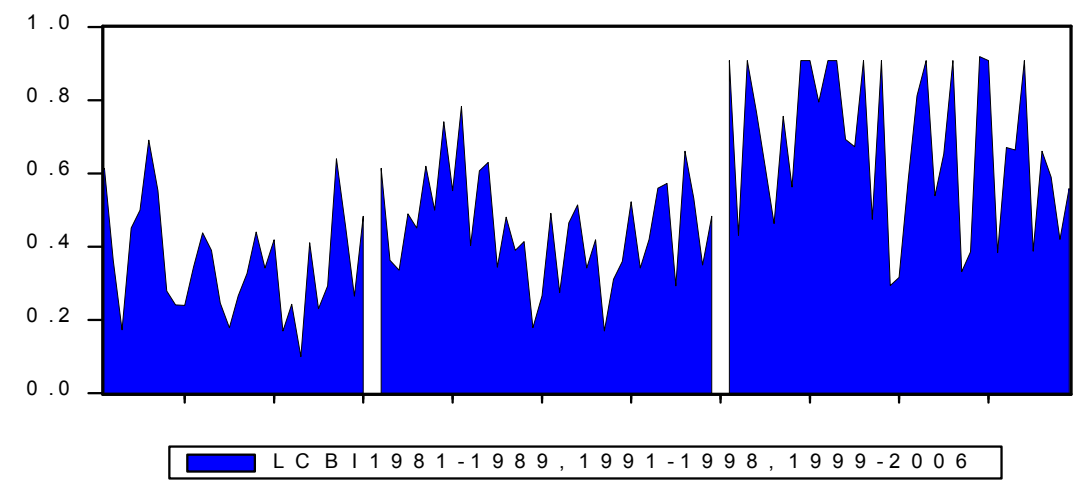

3.2. Macroeconomic Performance: Assessing the Relative Importance of Central Bank Independence

To assess the practical significance of central-bank independence for economic outcomes, the LCBI scores in Graph A.1 have been regressed on three indicators of macroeconomic performance: inflation, INFL (measured by

extended the CWN index to twenty-six former socialist countries for 1989-1998, while Arnone et al.(2006) have constructed updated indices for a number of developed and developing countries on the basis of both the Cukierman et al. (1992) and the Grilli et al. (1991) methodology. Crowe \& Meade (2008) have produced legal independence indices for 2003 for many counties in the Cukierman et al. (1992) sample. Polillo \& Guillen (2005) provide values for legal CBI levels based on the Cukierman et al. (1992) codings for a sample of 90 countries for 1990-2000.

${ }^{12}$ Appendix Table A.1 reports the $L C B I$ series, while Table A.2 reports information on the central-bank legislation used for updating CWN scores for 1991-1998 and 1999-2006. The CWN measure is based on 16 characteristics of central banks' (CBs) charters, grouped into four main categories: (i) the term of office, the procedures for appointment and for dismissal of the CB's governor and the extent to which the government participates in the CB's board (4 main components); (ii) who has the responsibility for formulating monetary policy, who has the final say in the resolution of conflict with the government and to what extent the CB participates in the budget process ( 3 main components); (iii) the CB's objectives; (iv) limitations on the CB's ability to provide credit to the public sector (8 main components, involving (a) limits on advances to the government, (b) restrictions on securitized lending, (c) terms of lending (maturity, interest rates, amount), (d) whether or not all levels of government have access to CB lending, (e) how limits on CB lending are defined, (f) maturity of loans, (g) interest rates on loans, (h) restrictions on buying/selling government securities by the central bank). The individual items in (i) are aggregated into one variable by computing their mean. The three components in (ii) are aggregated by computing their weighted sum, using a weight of 0.25 for who has the responsibility for formulating monetary policy, 0.5 for resolution of conflict, and 0.25 for active role of CB in the government budget. The objectives variable in (iii) is assessed separately. In (iv) the first four components (i.e. (a) to (d)) are taken separately, while the other four items (i.e. (e)-(h)) are averaged with equal weights to form one variable. This leads to one summary value for each of the items (i), (ii) and (iii) and five values for items (iv), giving a total of eight figures. These eight figures are then averaged with equal weights, leading to a single measure for each country and relevant period. For details of the CWN codings and of the legislation that has amended central-bank functions, which has led to the updates for 1991-1998 \& 1999-2006, see Anastasiou (2009). 
the modified inflation rate $\frac{\pi}{1+\pi}$, where $\pi$ is the $\log$ difference of GDP deflator ${ }^{13}$ ), employment growth, $E M G$ (measured by the log difference of total employment), and short-run output volatility following supply-side shocks, GDPRES, proxied by the ratio of the output gap (percentage deviation of real GDP from trend) to the standard deviation of real effective exchange rates. Control variables commonly used in the literature are examined together with a set of other variables to which existing studies often give little attention. Thus, in addition to indicators of the fiscal-policy stance, of the exchange-rate regime and of openness, we also use as control variables proxies for publicsector institutional quality, for product-\& financial-market liberalization, and for labour-market-flexibility and labourproductivity conditions. Institutional quality in the public sector, GQUAL, is measured by an overall governmentquality indicator constructed by QOG (Quality-of-Government Institute, QOG database, ICRG Indicator of QoG), which assesses bureaucracy quality, corruption and law $\&$ order. Market liberalization is proxied by three economicglobalization indicators. Two of them are from Dreher (2006) and Dreher et.al. (2008). ${ }^{14}$ The first, $L I B D F$, is based on the size of economic flows (trade, FDI and portfolio investment, scaled by GDP), while the second, LIBDT, also accounts for restrictions on current and capital transactions. The third economic-globalization index, LIBGT, is from Gwartney et.al.(2009) ${ }^{15}$ and also reflects overall market liberalization. All three market-liberalization proxies, LIBDF, $L I B D T$, and $L I B G T$, as well as the government-quality proxy GQUAL, are re-scaled so as to vary between 0 and 1 to allow for a direct comparison of the corresponding estimated coefficients with those of $L C B I$, with a higher value indicating greater government-quality/market-liberalization. To capture domestic financial-sector developments, following e.g. Neyapti (2001), we also include in the set of explanatory variable real lending rates, RLEND. Labourmarket control variables consist of proxies for real-wage rigidity, individual labour-supply flexibility, and unemployment rigidity. These are represented, respectively, by trade-union power, measured by union density $D E N S$ (ratio of trade-union members to the labour force), active labour-market policies ALMP (measured by the ratio of public expenditure on such policies to GDP), and relative strictness of employment-protection legislation, EMPR. An index of overall labour productivity, $P R O D$ (or relative unit-labour costs in manufacturing, ULCM), is also included in the set of control variables as a proxy for incentive structures. Other control variables that we take into account are fiscal deficits, $D E F$, scaled by GDP, the standard deviation of nominal effective exchange rates, $N E X V$, and openness, OPEN, defined as the average of exports and imports in GDP.

$A L M P$ and EMPR data are from the $\operatorname{OECD}^{16}$ (Labour Market database and Employment Outlook), with the original OECD index for $E M P R$, which varies between 1 and 6, being rescaled so as to take a maximum value of 1 to allow for direct comparison of the estimated coefficient with those of $L C B I$. The $D E N S,{ }^{17} P R O D^{18}$ and $U L C M^{19}$

\footnotetext{
${ }^{13}$ The modified inflation rate is commonly used in the empirical cross-country CBI literature to reduce heteroskedasticity (see e.g. Berger $e t$. al. (2001) and Klomp \& De Haan (2010a)).

${ }^{14}$ KOF index of economic globalization, KOF Swiss Economic Institute, Zurich. In its original form, the index has a maximum value of 100.

${ }^{15}$ Freedom-to-trade-internationally dataset, Fraser Institute, Vancouver. The LIBGT index takes account of restrictions to engage in product- and capital-market exchanges with foreigners, as well as trade \& capital flows. In its original form, it varies between 1 and 10 .

${ }^{16}$ For Estonia, Slovenia and Bulgaria the EMPR and/or ALMP entries for 1991-1998 are based on the figures reported in Cazes \& Nesporova (2005) for the 1990s (see also Leetmaa \& Vơrk (2003) for ALMP values in Estonia). For 1999-2006, for Bulgaria, Estonia, Latvia, Lithuania, Slovenia and Romania, the ALMP figures are from the LMP database of Eurostat (Labour Market Policies, categories $1+$ 2 to 7 , years 2003/2004) while the EMPR entries are based on the figures reported in Ciuca et al. (2009) and Muravyev (2010). ALMP and $E M P R$ figures for Israel are based on OECD (2010).

${ }^{17}$ OECD and Visser (2011).
} 
series are based on data also drawn mainly from the OECD, and the original series have been divided by 100, again to allow for a direct comparison of the point estimates of the corresponding coefficients with those associated with $L C B I$. Fiscal-deficit data are from the IMF (World Economic Outlook database), ${ }^{20}$ while the series for lending rates and openness are based on data from the World Bank (World Development Indicators) and from Eurostat. Series for nominal/real effective exchange-rate variability have been constructed using data from the Bank for International Settlements (BIS database, Effective Exchange Rates).

Like the LCBI scores, control variables are measured as averages over the periods 1981-1989, 1991-1998 and 1999-2006. ${ }^{21}$ Inflation, employment growth and short-run output-response to supply-side shocks are measured with a two-year period lag, that is, as averages over the periods 1983-1989, 1993-1998 and 2001-2006, to address reverse causation. ${ }^{22}$ The statistical properties of the dataset are shown in Appendix Table A. Standard regressions with White-heteroskedasticity-robust standard errors are presented in Tables 1.1-3.1, while results using MCMC methods for estimation from a Bayesian perspective are reported in Tables 1.2-3.2.

\subsection{Estimation Results}

\subsubsection{Standard Regressions}

Table 1.1 presents results explaining inflation. Column (a) is consistent with the widely held view that higher central-bank independence improves inflation outcomes, with the $L C B I$ coefficient having a negative sign and being significant at $1 \%$. But $L C B I$ in column (a) can explain only a small part of the overall variation in inflation rates. In columns (b)-(r) additional explanatory variables are introduced and the estimates suggest that factors other than central-bank independence have a stronger impact on inflation outcomes. Thus, higher public-sector institutional quality always reduces inflation, with the government-quality proxy GQUAL having a negative sign and being highly significant throughout Table 1.1, and the overall fit of the regressions greatly improved compared to column (a). ${ }^{23}$ LIBDF, LIBGT and LIBDT enter in the regressions in columns (c)-(e), (g)-(j) and (m)-(o) significantly and with a negative sign, increasing the explanatory power of the model and suggesting that market liberalization matters for price stability, whatever the level of central-bank independence. Moreover, the point estimates of the coefficients associated with GQUAL, $L I B D F, L I B D T$ and $L I B G T$ are on average three to four times larger than the estimated $L C B I$ coefficients. Given that $L C B I, L I B D F$, $L I B D T$ and $L I B G T$ are measured on a similar scale, this

\footnotetext{
${ }^{18} \mathrm{OECD}$ Labour productivity per unit of labour input (Main Economic Indicators database, 2005=100) and Labour productivity index (2005=100). Own calculations for Malta and Romania for 1991-1998 \& 1999-2006 based on real GDP and employment data. An increase in $P R O D$ refers to higher labour productivity.

${ }^{19}$ OECD Unit labour cost in manufacturing (Main Economic Indicators database, index 2005=100). For Greece and Switzerland the figures refer to total economy. An increase in $U L C M$ refers to higher unit-labour costs.

${ }^{20}$ Fiscal-deficit data for Bulgaria, Romania, Hungary, Poland, Estonia, Slovenis, Latvia and Lithuania are from Eurostat. The source of the fiscal-deficit data for Mexico is the Secretaria de Hasienda y Credito Publico, Mexico.

${ }^{21}$ The entries for 1981-1989 for GQUAL, ALMP and EMPR are the 1984-1985 figures, as comparable data prior to 1984 are not available. For the same reason, the entries for 1991-1998 for the majority of the NEUMs are the 1994-1995 figures.

${ }^{22}$ The inflation series for the countries in our sample are constructed from nominal and real GDP data drawn from the IMF (International Financial Statistics). Employment data are from the IMF and ILO, except for Mexico and Latvia \& Lithuania for which OECD and Eurostat data have been used respectively. For the majority of the OECD countries considered, GDPRES has been constructed using output-gap data from the IMF (World Economic Outlook). In the case of countries for which no IMF data were available a Hodrick-Prescott (HP) filter was used to obtain series for trend output.

${ }^{23}$ To the extent that public-sector institutional quality can be assumed to be related to the degree of constraints on politicians, this result is in accordance with Acemoglu et.al. (2008), who, using dummies for high-, medium- and low-constraints on political-office holders in national economies, find evidence suggesting that CBI has a negative effect on inflation in intermediate-constraint economies but does not influence inflation in high-constraint economies.
} 
suggests that institutional quality in the public sector and market liberalization are far more important determinants of low inflation than central-bank independence per se. Indeed, in all the specifications, the $L C B I$ variable loses part of, or all of, its significance at standard levels when $L I B D F$, LIBDT or LIBGT are added, indicating no strong relationship between inflation and central-bank independence once market liberalization is accounted for.

\section{TABLE 1.1}

As far as labour-market control variables are concerned, higher union density, through a greater bargaining power of trade unions, can lead to larger departures of real wages from the marginal product of labour, producing an increase in an economy's inflation bias. Active labour-market programs, through financial incentives for starting up new business, through workers' training, and thus enhanced human capital, and through subsidizing part of firms' social-security contributions for new labour-market entrants, are likely to contribute to reducing production costs and therefore inflation. Stricter employment-protection legislation can lead to increased costs of firing and hiring workers, and more generally to a deterioration of firms' flexibility to changing market conditions, which, other things equal, may push up prices. On the other hand, generalized structural reform leading to increased labour productivity can be expected to reduce inflation by lowering real unit-labour costs. Throughout Table 1.1, all the labour-market variables have the expected sign and, with the exception of the employment-protection proxy, are highly significant in most specifications. Thus, $P R O D$ enters in columns (f)-(j) with a significantly negative, and relatively large in size, coefficient. Including PROD increases the overall fit of the regressions relative to columns (b)-(e), reducing the size and/or significance of the $L C B I$ coefficient, with the significance of the public-sector quality proxy $G Q U A L$ remaining the same. The DENS coefficient always has the expected positive sign, while controlling for union power causes a drop in the estimated $L C B I$ coefficient increasing at the same time the overall explanatory power of the model (see e.g. columns (h) and (k)).The ALMP variable enters significantly and with the correct negative sign in columns (l)-(o) and (q)-(r) and adding it further improves the fit of the regressions. At the same time, the coefficient of $D E F$ is significantly positive in columns (o), (p) and (r), confirming that large fiscal deficits increase inflation. In columns (p)-(r) $N E X R V$ also enters with a significantly positive coefficient, confirming that exchangerate variability exerts an unfavourable influence on inflation, with the point estimate of the $L C B I$ coefficient remaining small and on average less significant than the coefficients of other explanatory variables, such as GQUAL, DENS and ALMP. Overall, the results in Table 1.1 appear to provide support for the idea that lower inflation should be seen as resulting from a broad-range of structural and institutional factors, with CBI failing to play the key role: institutional quality in the public sector, market integration, labour-market characteristics, fiscal deficits and exchange-rate variability have on average a stronger impact on price stability than central-bank independence per se. Only the employment-protection variable is insignificantly related to inflation in all the specifications in Table 1.1, while real lending rates have no uniform effect on inflation outcomes, something which can be explained by the fact that a rise in RLEND will tend to increase prices as firms will seek to preserve profit margins after the rise in their interest payments but will also lower inflation through reduced aggregate demand.

Table 2.1 presents results on employment performance. On theoretical grounds, other things equal, higher central-bank independence may have a positive effect on employment growth by increasing the credibility of 
commitments to price stability. ${ }^{24}$ Indeed, in column (a), higher central-bank independence appears to be associated with a higher rate of employment growth. This is reversed, however, once other relevant factors are included as explanatory variables. In particular, in columns (b)-(p), we add as explanatory variables real GDP growth, GDPG, to account for an Okun relationship; market liberalization, $L I B D F$, LIBDT and LIBGT, to allow for the opening up of markets to influence employment outcomes; relative unit-labour cost in manufacturing, $U L C M$, to control for the role in employment growth of cross-country profitability differences (and therefore incentive structures); union density, $D E N S$, as an indicator of real-wage rigidity; and active labour-market policies, $A L M P$, and relative strictness of employment-protection legislation, $E M R P$, as proxies for quantity-flexibility in the labour market. Other control variables, corresponding to the inflation regressions in Table 2.1, that we also take into account are fiscal-deficit variability, $D E F V$, public-sector institutional quality, GQUAL, real lending rates, $R L E N D$, nominal effective exchange-rate variability, $N E X V$, and openness, $O P E N$.

TABLE 2.1

In none of the regressions in columns (b)-(p) is the $L C B I$ variable significantly positive, while all the other explanatory variables always have the expected sign and are in almost all cases significant at standard levels. Thus, throughout Table 2.1, GDPG and ULCM enter with the expected positive and negative sign respectively, with the associated coefficient estimates significant at $1 \%$ or $5 \%$. In columns (c)-(h), the coefficients of $L I B D F$, LIBDT and $L I B G T$ are positive and significant, confirming the role of the opening-up of markets as one of the determinants of high employment growth. Increased public-sector institutional quality also has a positive effect on employment growth, with the GQUAL variable in columns (k)-(m) showing a positive and statistically significant coefficient. The DENS variable, through real-wage rigidity, has a significantly negative coefficient (columns (m), (o) and (p)), while ALMP, through a higher rate of matching and training workers for jobs, enters in the regressions in columns (o) and (p) significantly and with a positive sign, something which in line with other studies (Bassanini \& Duval (2006); Ederveen \& Thissen (2007); Kluve (2010)). EMPR appears to have no strong overall adverse impact on employment growth in Table 3.1, which can be explained by the fact that stricter employment protection slows down long-term hiring but limits short-term firing and/or leads to substitution of temporary jobs for permanent ones (Belot \& Van Ours (2004); Baker et al. (2005); Kahn (2010)). On the other hand, the $D E F V$ coefficient is significantly negative in columns (f), (h), (j) and (p), confirming that budget-deficit variability is harmful for employment growth, with the inclusion of the $D E F V$ variable in the regressions causing no reversal in the sign of the $L C B I$ coefficient. Increased openness also reduces domestic employment-growth rates (columns (i)-(j))), while higher real lending rates in columns (n)-(p) have a negative, although not statistically significant, effect on employment outcomes. At the same time, the $L C B I$ coefficient remains negative throughout columns (b)-(p) and is statistically significant at standard levels in columns (c)(f) and (o)-(p), implying no favourable effect of central-bank independence on employment performance once other relevant factors are controlled for.

Results on the role of central bank independence in output volatility over the cycle following supply-side shocks are shown in Table 3.1. While much of the analytical CBI literature suggests that higher central-bank independence, by limiting the scope for monetary stabilization, can lead to larger short-run deviations of real

\footnotetext{
${ }^{24}$ Higher employment growth may result from increased credibility. The credibility gain is much stressed in the CBI literature (see e.g. Posen (1998); Blinder (2000)).
} 
output from trend in response to supply-side shocks, a large part of the empirical CBI literature fails to provide clear evidence in support of this hypothesis. One explanation is that central-bank independence reduces the politicallyinduced business cycle and this compensates for the higher volatility of output associated with increased CBI in the presence of real stochastic shocks (Alesina \& Gatti (1995); Demertzis (2004)).Another explanation is that there may be a problem of reverse causality: governments may be reluctant to grand independence to monetary policymakers if their economies are subject to large supply-side fluctuations (Alesina \& Grilli (1992); Crosby (1998)). In an attempt to deal with this possibility, some studies regress a proxy for real shocks on indicators of CBI and use the residuals as an explanatory variable in regressions for output volatility. Here, to address the reverse-causality possibility, we attempt to examine directly to what extent higher CBI may affect the average short-run output response to supply-side shocks. To this end, and using the variability of the real exchange rate as a proxy for supply-side shocks, we regress the $L C B I$ scores on the ratio of the output gap (percentage deviation from trend) to the standard deviation of realeffective exchange rates, treating this ratio, GDPRES, as a proxy for the way output on average reacts to real shocks in the short run. We also include as additional explanatory variables, the index GQUAL for public-sector institutional quality, the proxies $D E N S, A L M P$ and $E M P R$ for labour-market characteristics, the product-market integration proxy $\angle I B D F$ and the fiscal-policy proxy $D E F$. Because comparable real effective exchange-rate data for all the countries in our sample are not available prior to 1990, we restrict our pooled sample to the 1991-2006 period. $^{25}$

\section{TABLE 3.1}

In column (a) of Table 3.1 the $L C B I$ variable enters with a positive and significant coefficient, suggesting that real shocks tend to be accompanied by larger short-run deviations of output from trend the higher is centralbank independence. Additional explanatory variables are included in columns (b)-(j). Starting with DENS, the existence of unions may affect the response of output to real shocks over the cycle through two different routes. On the one hand, if union power is strong, higher real-wage rigidity is likely to prevail, in which case unemployment can be expected to rise more following an adverse supply-side shock, leading to larger departures of output from trend. This suggests a positive relationship between GDPRES and DENS. At the same time, more powerful unions may resist massive firing of workers following adverse supply-side shocks, forcing firms to resort to cuts in profit margins rather than cuts in employment and thus in production. This would imply a negative relationship. In general, both effects may work, something reflected in the statistically insignificant coefficient associated with $D E N S$ in column (c). Stricter employment-protection legislation reduces firms' flexibility to fire old (or hire new) workers, with the result that employment adjusts less abruptly to real shocks in the short run, reducing output volatility. Thus, the $E M P R$ variable has the correct negative sign, with the associated coefficient estimate significant in columns (d), (f) and (g). Active labour-market policies, through the financing of employment programmes for those who lose their job and through subsidizing the social-security contributions of firms for new labour-market entrants, introduce more flexibility in labour supply, constraining the size of the output gap following adverse real shocks. This is reflected in the negative coefficient (although not always significant) of the ALMP variable in columns (e)-(g) and (i)-(j).Controlling for employment protection and/or active labour-market policies also makes the DENS coefficient

\footnotetext{
${ }^{25}$ Latvia, Lithuania, Estonia and Slovenia were not included as their real-GDP series were not long enough to extract a meaningful trend in the HP series. Bulgaria, Romania, Poland, Hungary and the Czech Republic were also excluded from the estimation in Tables $3.1 \& 3.2$ as their trend output showed significant variability in the HP series, something that could have biased the results.
} 
significantly positive in columns (e)-(g) and (i)-(j) as quantity flexibility in the labour market is directly captured by $E M P R$ and $A L M P$, thus allowing DENS to reflect real-wage-rigidity effects. In column (g), market integration, $L I B D F$, increases short-run output volatility, although the associated coefficient is not significant at standard levels, something consistent with the findings of other studies. ${ }^{26}$ At the same time, as would be expected, columns (b)-(j) imply a negative association between the size of the output gap following real shocks and institutional quality in the public sector (the coefficient of GQUAL has a negative sign throughout and is always significant at $1 \%$ or $5 \%$ ). The estimates in Table 3.1 also indicate a stabilizing, counter-cyclical, role of fiscal policy in the short run, with the coefficient of $D E F$ in columns (h) to (j) implying an inverse, and highly significant, relationship between the size of the output gap following real shocks and the size of fiscal deficits. In general, while all the control variables in Table 3.1 have the expected signs, the $L C B I$ coefficient always has a positive sign and is statistically significant. Overall, therefore, the results in Table 3.1 suggest that, even after controlling for institutional quality in the public sector, labour-market characteristics, product-market integration and the fiscal-policy stance, greater central-bank independence tends to produce less stable output outcomes over the cycle in the presence of real shocks.

\subsubsection{Sensitivity Analysis Using MCMC Estimation Methods from a Bayesian Perspective}

We now proceed to examine the robustness of the results reported in Tables 1.1-3.1 by adopting Markov-Chain Monte-Carlo (MCMC) methods for estimation from a Bayesian perspective. MCMC methods for estimation from a Bayesian perspective are believed to improve result robustness by increasing parameter accuracy and reducing the effect of outlying observations. ${ }^{27}$ Stochastic simulation provides an estimation method for determining parameters of interest from marginal probability distributions.Simulation of the marginal distribution is obtained with the use of stochastic processes (e.g. Gibbs Sampler, Metropolis Hasting). Here we use the Gibbs Sampler (GS). ${ }^{28}$ This estimation procedure allows draws to be made on the marginal posterior distribution without having to calculate the density, by iteratively sampling on the conditional posterior for different blocks of parameters.

In particular, let the relationship to be estimated be written as $Y_{h}=X b_{h}+\varepsilon_{h}$, where the $h(h=1,2,3)$ refers to each of the three measures of macroeconomic performance considered, $Y$ is a $T$-dimensional vector of observations on a dependent variable, $X$ is a ( $T x K$ ) matrix of observations on $K$ non-stochastic explanatory variables, consisting of the $L C B I$ scores and the other control variables (and possibly including a constant term), $\beta$ is a $K$-dimensional vector of unknown coefficients that we wish to estimate and $e$ is a $T$-dimensional unobserved random vector, assumed to be distributed as $e \cup N\left(0_{T}, \sigma^{2} I_{T}\right)$ where $I_{T}$ is the $T x T$ identity matrix. The likelihood function for observing the vector of sample values $Y$, given $\beta$ and $\sigma^{2}$ (under the assumption of normality of the error term), is given as

$$
p\left(Y \mid \beta, \sigma^{2}\right)=\left(2 \pi \sigma^{2}\right)^{-\frac{T}{2}} \exp \left[-\frac{1}{2 \sigma^{2}}(Y-X \beta)^{\prime}(Y-X \beta)\right]
$$

\footnotetext{
${ }^{26}$ See e.g. Di Giovanni \& Levchenko (2009) and the papers cited there. Di Giovanni \& Levchenko (2009) report evidence of a positive relationship between output volatility and the opening up of markets but find that the strength of the effect varies with country characteristics.

${ }^{27}$ See e.g. Gamerman \& Lopes (2006) for MCMC methods.

${ }^{28}$ See Casella \& George (1992) for an introduction to the algorithm.
} 
which, following Koop (2003), can be represented in a more convenient way for the purposes of Bayesian inference as:

$$
p\left(Y \mid \beta, \sigma^{2}\right)=(2 \pi)^{-T / 2}\left\{\frac{1}{\sigma} \exp \left[-\frac{1}{2 \sigma^{2}}(\beta-\hat{\beta})^{2} X^{\prime} X\right]\right\}\left\{\frac{1}{\sigma^{v}} \exp \left[-\frac{v s^{2}}{2 \sigma^{2}}\right]\right\}
$$

where

$$
s^{2}=\frac{(Y-X \hat{\beta})^{\prime}(Y-X \hat{\beta})}{v}, \hat{\beta}=\left(X^{\prime} X\right)^{-1}\left(X^{\prime} Y\right), v=T-K=\text { degrees of freedom. }
$$

As prior density we assume that our information is diffuse or vague and represent it by

$$
\begin{aligned}
p\left(\beta, \sigma^{2}\right) \propto \frac{1}{\sigma} & -\infty<\beta<\infty \\
\sigma & >0
\end{aligned}
$$

Following the Bayes theorem (also known as the principle of inverse probability, see Zellner (1971)) we can write for the posterior density function

$$
p\left(\beta, \sigma^{2} \mid Y\right) \propto\left\{\frac{1}{\sigma^{2}} \exp \left[-\frac{1}{2 \sigma^{2}}(\beta-\hat{\beta})^{2} X^{\prime} X\right]\right\}\left\{\frac{1}{\sigma^{v}} \exp \left[-\frac{v s^{2}}{2 \sigma^{2}}\right]\right\}
$$

The form of (3) suggests that the conditional posterior density for $\beta \mid \sigma^{2}, Y$ is multivariate normal (MVN), i.e. $\beta \mid \sigma^{2}, Y \sim M N\left(\hat{\beta}, \sigma^{2}(X X)^{-1}\right)$, with posterior mean equal to $E\left(\beta \mid \sigma^{2}, Y\right)=\hat{\beta}=\left(X^{\prime} X\right)^{-1} X^{\prime} Y$, and posterior covariance matrix equal to $V\left(\beta \mid \sigma^{2}, Y\right)=\sigma^{2}\left(X^{\prime} X\right)^{-1}$. Viewing the posterior density function as a function of $\sigma^{2}$ yields the conditional posterior density for $\sigma^{2} \mid \beta, Y$, that is, the Inverted Gamma (IG):

$$
\sigma^{2} \mid \beta, Y \sim I G\left(v, s^{2}\right)
$$

which has $v$ degrees of freedom and parameter matrix $\mathrm{s}^{2}$.

Knowledge of the conditional distributions is only useful if there are methods that can use these conditionals to get to the joint or marginal density. Drawing sequentially from the conditional distributions for the blocks of the unknown parameters of the model, it can be shown after a relatively large number of iterations these draws will converge to draws on the marginal posterior density. The Gibbs algorithm proceeds as follows: Step 1: select starting values for $\beta$; Step 2: draw $\sigma^{2}$ from the IG; Step 3: draw $\beta$ from the MVN; Step 4: repeat steps 2 and 3 many times, until convergence is obtained. ${ }^{29}$

Detecting the convergence of the Gibbs Sampler is still an issue in the literature. ${ }^{30}$ Here, apart from visual plots of the parameters produced by the Gibbs Sampler, a fairly simple and convenient convergence diagnostic tool is used to check for the stationary of the chain. During the sampling procedure we divide the sequence of draws into four parts. Discarding the first part of the draws (the "burn-in phase") results in the removal of the effect of the starting value. With the use of a convergence indicator (ci) we then compare the mean values of all

\footnotetext{
${ }^{29}$ Programmes for sampling are created in the environment of GAUSS matrix-programming software package.

${ }^{30}$ See Cowles \& Carlin (1996) for a discussion of different convergence diagnostics. See also Gamerman \& Lopes (2006) for a more general treatment.
} 
the parameters from the second and fourth part. In particular, letting $k_{B}$ and $k_{D}$ be the mean values of the parameter draws from the second $(B)$ and fourth part $(D)$ respectively, the convergence indicator $(c i)$ is formulated as

$$
c i=\sum_{i=1}^{g}\left(k_{i D}-k_{i B}\right)^{2}
$$

with $g$ being the total number of draws in the two parts $(B)$ and $(D)^{31}$ where the draws are stored after each loop. Convergence is taken to have been obtained when the difference between the two parts of the chain is close to zero. This can be visually represented by the graph of the convergence indicator, $c i$ ( $c i$ will fall close to zero and stay there).

The results for inflation, employment growth and short-run output response to real shocks are shown, respectively, in Tables 1.2, 2.2 and 3.2. The tables report posterior means, standard deviation (in brackets) and HPDIs (Bayesian, Highest Posterior Density Intervals) (in squared brackets) for the estimated parameters, obtained from 10,000 GS iterations and "burn in" phase of 500 iterations (5\%). Parameter robustness can be based on the HPDIs (a 95\% HPDI for a parameter $\beta$ is interpreted as the interval containing $\beta$ with $95 \%$ probability). Graphical representation of the parameter draws produced by the Gibbs Sampler and visual plots of the convergence indicator are shown in Graphs 1.2-3.2.

\section{TABLE 1.2}

Table 1.2 shows that central-bank independence plays a supportive but not the key role in inflation outcomes, while all the control variables considered, except for real lending rates and strictness of employment protection, are robustly related to inflation. In particular, columns (i)-(xii) and (ii)-(x), respectively, imply a robustly favourable effect of increased public-sector institutional quality and market liberalization on price stability, with the GQUAL, $\angle I B D F, L I B D T$ and $L I B G T$ parameter point estimates showing negative, and relatively large in absolute magnitude, posterior means and no change in sign in the HPDIs. Similar considerations apply to the real-wage-rigidity proxy $D E N S$ in columns (v)-(xii) and to the labour-productivity variable $P R O D$ in columns (v)-(vii), where posterior means for the corresponding parameters are positive and negative respectively and relatively large in size. The ALMP coefficient also shows a negative posterior mean and no change in sign in the $95 \%$ credible intervals in columns (viii)-(xii), suggesting a favourable impact of active labour-market policies on maintaining price stability. On the other hand, the properties of the EMPR parameter in Table 1.2 indicate that stricter employment protection is weakly related to inflation, with the corresponding HPDI in columns (viii), (ix) and (xi) including a zero value. Fiscal deficits and exchange-rate variability increase inflation (posterior means and 95\% HPDIs for the $D E F$ and $N E X V$ coefficients in columns (x)-(xii) are positive), while the RLEND coefficient has no uniform sign, which can be explained by the fact that higher real lending rates tend to push up prices through the supply side but also reduce aggregate demand. At the same time, in all cases in columns (i)-(xii), the point estimates of the $L C B I$ coefficient drop significantly as additional controls are introduced. Moreover, posterior means for the $L C B I$ parameter are on average smaller in absolute magnitude than those for other explanatory variables which are measured on a similar scale (e.g. GQUAL, LIBDF, LIBDT, LIBGT, DENS, PROD), confirming that factors other than central-bank independence

\footnotetext{
${ }^{31}$ The size of these parts is not constant. The number of draws expands progressively as the number of iterations increases and more draws are stored.
} 
have a relatively stronger impact on inflation outcomes. Graphs 1.2(i)-1.2(xii) illustrate graphically the outcomes for the parameter coefficients.

The results in Table 2.2 show that the effect of central-bank independence on employment growth is consistently negative, while all the other explanatory variables are correctly signed and exert a robust influence on $E M G$. Thus, posterior means and HPDIs for the coefficients of output growth $G D P G$, overall market liberalization LIBDT and LIBGT (columns (ii)-(vi)) and public-sector institutional quality GQUAL (columns (viii)-(ix)) are always positive. The coefficients of relative unit-labour costs in manufacturing, fiscal-deficit variability (columns (iv), (vi)-(vii) and (xi)), union density (columns (ix)-(xi)) and real lending rates (columns (x)-(xi)), all have negative posterior means and show no sign change in the 95\% HPDIs. Active labour-market policies, ALMP, exert, as would be expected, a positive influence on employment outcomes in columns (x) and (xi). Stricter employment protection overall has an unfavourable impact on employment in Table 2.2 (posterior means and 95\% credible intervals for the EMPR coefficient in columns (x)-(xi) is negative). Increased openness lowers domestic employment growth, while nominal exchange-rate variability does not seem to influence employment outcomes (the point estimate of the corresponding parameter is zero in column (vii)). At the same time, in all the specifications, posterior means and $95 \%$ HPDIs for the $L C B I$ parameter are negative, suggesting the absence of any favourable effect of central-bank independence on employment once other relevant factors are included as explanatory variables. Graphs 2.2(i)2.2(xi) show graphically parameter convergence.

\section{TABLE 2.2}

The results in Table 3.2 confirm that central-bank independence increases rather than decreases short-run output volatility in the presence of real shocks, even when other relevant variables are controlled for. In particular, posterior means for the GQUAL coefficient are large in absolute magnitude and retain their negative sign in the 95\% HPDIs throughout Table 3.2, implying a robustly favourable effect of public-sector institutional quality on output stability over the cycle. The union-density coefficient changes sign in the $95 \%$ credible interval in column (ii) but becomes robustly positive and large in size when the labour-market flexibility proxies EMPR and/or $A L M P$ are also included (columns (iv)-(viii)). The $A L M P$ and $E M P R$ variables show coefficients with negative posterior means and no change in sign in the HPDIs, confirming that active labour market policies and employmentprotection legislation tend to dampen short-run output volatility following real shocks. Increased market integration, $L I B D F$, has a robustly positive effect on short-run output volatility in Table 3.2 (posterior mean and HPDIs for the $L I B D F$ coefficient are positive in column (vi)), while the negatively-signed posterior means and 95\% HPDIs for the $D E F$ parameter in columns (vii)-(viii) suggest that fiscal policy always plays a stabilizing, counter-cyclical, role through the automatic stabilizers of the budget (and/or possibly through counter-cyclical discretionary fiscalpolicy responses). At the same time, throughout Table 3.3, posterior means and credible intervals for the $L C B I$ parameter indicate an unfavourable influence of central bank independence on the volatility of output following supply-side shocks. Graphs 3.2(i)-3.2(viii) illustrate visually that the draws for the unknown parameters of interest in Table 3.3 are centred around the reported mean point estimates.

TABLE 3.2

\section{Concluding comments}


There has been a large body of literature since the mid-1990s examining the effects of the increased independence of monetary policy-makers. However, despite the growing literature, the empirical evidence regarding the role of central bank independence in macroeconomic outcomes still remains mixed: while much of the early CBI literature suggested that politically independent central banks could achieve lower inflation than central banks in which this independence was absent, and indeed at no cost in terms of creating lower employment or higher output instability, more recent studies have questioned the robustness of these results, pointing to omitted variables. This has raised doubts as to whether CBI really matters once other factors that may also influence macroeconomic performance are taken into account.

Using both standard regressions and Markov-Chain Monte-Carlo estimation methods from a Bayesian perspective and a sample consisting of 39 countries covering the period 1981-2006, our results suggest that the favourable effect of $\mathrm{CBI}$ on inflation stressed in much of the literature is overstated: we find a negative but on average no strong association between higher independence and inflation, which is not robust to the inclusion of several control variables. Other factors appear to contribute more than central bank independence to price stability, and our estimates imply that institutional set-ups in other parts of the economy, incentive structures and other marketreform efforts have been important elements in enabling the countries in our sample to reduce inflation rates. At the same time, higher central-bank independence is found to have no favourable impact on employment growth once other relevant variables are allowed for, with increased commitments to price stability associated with CBI failing to play any significant positive role. Moreover, higher independence of national monetary authorities increases rather than decreases short-run output volatility following supply-side shocks. This is found to hold even after controlling for institutional quality in the public sector, labour-market variables and the fiscal-policy stance.

\section{References}

Abbritti, M. and Weber, S. (2010) 'Labour market institutions and the business cycle: unemployment rigidities versus real wage rigidities' ECB Working Paper No. 1183.

Acemoglu, D., Johson, S., Queribin, P. and Robinson, J.A. (2008) 'When does reform work - the case of central bank independence', Brookings Papers on Economic Activity, Vol. 1/2008, 351-418.

Alesina, A. and Gatti, R. (1995) 'Independent central banks - low inflation at no cost?', American Economic Review, Vol. 85, $196-206$.

Alesina, A. and Grilli, V. (1992) 'The European Central Bank: reshaping monetary policy in Europe', in Canzoneri, M. et. al. (eds) Establishing a Central Bank: Issues in Europe and Lessons for the US, Cambridge University Press, Cambridge, Mass.

Alesina, A. and Summers, L.H. (1993) 'Central bank independence and macroeconomic performance: some comparative evidence', Journal of Money, Credit and Banking, Vol. 25, 151-162.

Anastasiou, A.(2009) 'Central bank independence and economic performance', Cyprus Economic Policy Review, Vol. 3, 123-156.

Arnone, M., Laurens B.J. and Segalotto, J. (2006) 'Measures of central bank autonomy: evidence from OECD, developing and emerging market economies', IMF Working Paper No. 06/228, International Monetary Fund.

Baker, D., Howell, D. and Schmitt, J. (2005) 'Labour market institutions and unemployment: a critical assessment of the cross-country evidence' in Howell, D. (ed.) Fighting Unemployment: The Limits of Free Market Orthodoxy, Oxford University Press, Oxford, UK.

Banaian, K., Burdekin R., and Willett, T. (1998) 'Reconsidering the principal components of central bank independence: the more the merrier?', Public Choice, Vol. 97, 1-12.

Bassanini, A. and Duvall, R. (2006) 'Employment patterns in OECD countries: reassessing the roles of policies and institutions', OECD Economics Department Working Paper No. 486, OECD, Paris.

Belot, M. and Van Ours, J. (2004) 'Does the recent success of some OECD countries in lowering their unemployment rate lie in the clever design of their labour market reforms?', Oxford Economic Papers, Vol. 56, 621-642.

Berger, H. (2004) 'Optimal central bank conservatism and monopoly labour unions', IMF Staff Papers, Vol. 51, $585-605$.

Berger, H., De Haan, J. and Eijffinger, S., (2001) 'Central bank independence: an update of theory and evidence', Journal of Economic Surveys, Vol. 15, 1-38. 
Betcherman, G. (2012) Labour market institutions: a review of the literature, Background Paper for World Development Report 2013, World Bank.

Bibow, J.(2004) 'Reflections on the current fashion for central bank independence', Cambridge Journal of Economics, Vol. $28,549-576$.

Bleaney, M. (1996) 'Central bank independence, wage-bargaining structure and macro-economic performance in OECD countries', Oxford Economic Papers, Vol. 48, 20-38.

Blinder, A.S. (2000) 'Central bank credibility: where do we stand?, American Economic Review, Vol. 90, 1421-1431.

Bouwman, K. Jong-A-Pin R. and De Haan, J. (2005) 'On the relationship between central bank independence and inflation: some more bad news', Applied Financial Economics Letters, Vol. 1, 381-385.

Brumm, H.J. (2000) 'Inflation and central bank independence: conventional wisdom redux', Journal of Money, Credit and Banking, Vol.32, 807-819.

Brumm, H.J. and Krashevski, R.S. (2003) 'The sacrifice ratio and central bank independence revisited', Open Economies Review, Vol. 14, 157-168.

Campillo, M. and Miron, J.A. (1997) 'Why does inflation differ across countries?' in Romer, C.D. and Romer, D.H. (eds) Reducing Inflation: Motivation and Strategy, University of Chicago Press.

Campolmi, F. and Faia, E. (2011) 'Labour market institutions and inflation volatility in the euro area', Journal of Economic Dynamics and Control, Vol. 35, 793-812.

Carlstrom, C.T. and Fuerst, T. (2009) 'Central bank independence and inflation: a note', Economic Inquiry, Vol. 47, $182-186$.

Casella, G. and George E. (1992) 'Explaining the Gibbs Sampler', American Statistician, Vol. 46, 167-174.

Cazes, S. and Nesporova, A. (2005) Labour markets in transition - balancing flexibility and security in Central and Eastern Europe, International Labour Organization, Geneva.

Ciuca, V. Pasnicu, D., Son, L., Sipos, C. and Iordan, M. (2009) 'The Romanian flexisecurity - a response to the European labour market needs', Romanian Journal of Forecasting, Vol. 2, 161-183.

Cornwall, J and Cornwall, W. (1998) 'Unemployment costs and inflation targeting', in Arestis, P. and Sawyer, M. (eds), The Political Economy of Central Banking, Edward Elgar.

Cowles, M.K. and Carlin, B.P. (1996) 'Markov-Chain Monte-Carlo convergence diagnostics: a comparative review', Journal of the American Statistical Association, Vol. 91, 883-904.

Crosby, M. (1998) 'Central bank independence and output variability', Economic Letters, Vol. 60, 67-75.

Crowe, C. and Meade, E. (2008) 'Central bank independence and transparency: evolution and effectiveness', European Journal of Political Economy, Vol. 24, 763-777.

Cukierman, A. (2008) 'Central bank independence and monetary policymaking institutions - past, present and future', European Journal of Political Economy, Vol. 24, 722-736.

Cukierman, A., Kalaitzidakis, P., Summers, L. and Webb, S. (1993) 'Central bank independence, growth, investment and real rates', Carnegie-Rochester Conference Series on Public Policy, Vol. 39, 95-145.

Cukierman, A. and Lippi F. (1999) 'Central bank independence, centralization of wage bargaining, inflation and unemployment: theory and evidence', European Economic Review, Vol. 43, 1395-1434.

Cukierman, A and Lippi F.(2001) 'Labour markets and monetary union: a strategic analysis', Economic Journal, Vol. 111, $541-565$.

Cukierman,A., Miller, G.P. and Neyapti, B. (2002) 'Central bank reform, liberalization and inflation in transition economies', Journal of Monetary Economics, Vol. 49, 237-264.

Cukierman, A., Webb, S. and Neyapti, B. (1992) 'Measuring the independence of central banks and its effects on policy outcomes', The World Bank Economic Review, Vol.6, 353-398.

Daunfeldt, S.O. and De Luna, X. (2008) 'Central bank independence and price stability: evidence from OECD countries', Oxford Economic Papers, Vol. 60, 410-422.

Debelle, G. and Fischer, S. (1995) 'How independent should a central bank be?', in Fuhrer, J.C. (ed.) Goals, Guidelines and Constraints Facing Monetary Policymakers, Federal Reserve Bank of Boston, Conference Series No. 38.

De Haan, J. and Kooi, W.J. (2000) 'Does central bank independence really matters? New evidence for developing countries using a new indicator', Journal of Banking and Finance, Vol. 24, 643-664.

De Long, J. and Summers, L.H. (1992) 'Macroeconomic policy and long-run growth', Federal Reserve Bank of Kansas City Economic Review, Fourth Quarter/1992, 5-29.

Demertzis, M. (2004) 'Central bank independence: low inflation at no cost? A numerical simulation exercise', Journal of Macroeconomics, Vol. 26, 661--677.

Demertzis, M., Hughes-Hallett, A. and Viegi, N. (2003) 'An independent central bank faced with elected governments', European Journal of Political Economy, Vol. 20, 907-22.

Di Giovanni, J. and Levchenko, A. (2009) 'Trade openness and volatility', Review of Economics and Statistics, Vol. 91, 558-585.

Dreher, A. (2006) 'Does globalization affect growth? Empirical evidence from a new index', Applied Economics, Vol. 38, 1091-1110.

Dreher, A., Gaston, N., and Martens, P. (2008), Measuring globalization - gauging its consequences, Springer, N.York.

Ederveen, S. and Thissen, L. (2007) 'Can labour market institutions explain high unemployment in the new EU member states?, Empirica, Vol. 34, 299-317.

Floro, E.C. and Pastore, F. (eds) (2010) The labour market impact of EU enlargement: a new geography for Europe, PhysicaVerlag, Heidelberg, Germany.

Forder, J. (1998) 'The case for an independent European Central Bank: a reassessment of the evidence and sources', European Journal of Political Economy, Vol. 14, 53-71. 
Forder, J.(2001) 'The theory of credibility and the reputation bias of policy', Review of Political Economy, Vo. 13, 5-27.

Forder, J.(2002) 'Interests and 'independence': the European Central Bank and the theory of bureaucracy', International Review of Applied Economics, Vol. 16, 51-69.

Forder, J. (2005) 'Why is central bank independence so widely approved?', Journal of Economic Issues, Vol. 39, $643-845$.

Fry M., Julius D.A., Mahadeva, L., Roger, S. and Sterne, G. (2000) 'Key issues in the choice of monetary policy framework', in Mahadeva, L. and Sterne, G. (eds) Monetary Policy Frameworks in a Global Context, Routledge, London.

Fuhrer, J.C. (1997) 'Central bank independence and inflation targets: monetary policy paradigms for the next millennium?', New England Economic Review, Issue January, 19-36.

Gamerman, D. and Lopes, H.F. (2006) Markov-Chain Monte-Carlo Stochastic Simulation for Bayesian Inference, Chapman \& Hall/CRC.

Gärtner, M. (1997) 'Central bank independence and the sacrifice ratio: the dark side of the force', Swiss Journal of Economics and Statistics, Vol. 133, 513-538.

Grilli, V., Masciandaro, D. and Tabellini, G. (1991) 'Political and monetary institutions and public financial policies in industrial countries', Economic Policy, Vol. 13, 341-92.

Gutiérrez, E. (2004) 'Inflation performance and constitutional central bank independence: evidence from Latin American and Caribbean countries', Economia Maxicana, Vol. 13, 255-287.

Gwartney, J. and Lawson, R. with Grubel, H, de Haan, J., Sturm, J.E. and Zandberg, E. (2009). 2009 Economic Freedom dataset, The Fraser Institute, Vancouver, BC.

Hayo, B.,Hefeker P. and Hefeker, C. (2008) 'Does central bank independence cause low inflation? A sceptical view', Paolo Baffi Research Centre Paper No. 2008-04.

Hughes-Hallett, A. and Libich, J. (2012) 'Explicit inflation targets and central bank independence: friends or foes?, Economic Change and Restructuring, Vol. 45, 271-297.

Jäcome, L. and Väzquez F. (2008) 'Is there any link between central bank independence and inflation? Evidence from Latin America and the Caribbean', European Journal of Political Economy, Vol. 24, 788-801.

Jordan, T. (1999) 'Central bank independence and the sacrifice ratio', European Journal of Political Economy, Vol. 15, $229-255$.

Kahn, L.M. (2010) 'Employment protection reforms, employment and the incidence of temporary jobs in Europe, 19962001', Labour Economics, Vo. 17, 1-15.

Klomp, J. and De Haan, J. (2010a) 'Inflation and central-bank independence: a meta-regression analysis', Journal of Economic Surveys, Vol. 24, 595-621.

Klomp, J. and De Haan, J. (2010b) 'Central-bank independence and inflation revisited', Public Choice, Vol. 144, 445-457.

Kluve, J. (2010) 'The effectiveness of European active labour market programs', Labour Economics, Vol. 17, 904-918.

Koop, G. (2003) Bayesian Econometrics, Wiley, Chichester, UK.

Leetmaa, R. and Vơrk, A. (2003) 'Evaluation of active labour market policies in Estonia', University of Tartu, Estonia.

Lippi, F. (2003) 'Strategic monetary policy with non-atomistic wage setters', Review of Economic Studies, Vol. 70, 909-919.

Muravyev, A. (2010) 'Evolution of employment protection legislation in the USSR, CIS and Baltic States 1985-2009', IZA Discussion Paper No. 5365, December.

Neyapti, B. (2001) 'Central bank independence and economic performance in Eastern Europe', Economic Systems, Vol. 25, 381-399.

Nunziata, L. and Bowdler, C. (2005) 'Inflation adjustment and labour-market structure: evidence from a multi-country study', IZA Discussion Paper No. 1510, March.

OECD (2010) OECD Reviews of labour market and social policies: Israel, OECD, Paris.

Polillo, S. and Guillén, M. (2005) 'Globalization pressures and the state: the world under spread of central bank independence', American Journal of Sociology, Vol. 110, 1764-1802.

Posen, A. (1993) 'Why central bank independence does not cause low inflation? There is no institutional fix for politics', in O'Brien, R. (eds) Finance and the International Economy 7, Oxford University Press.

Posen, A. (1995) 'Declarations are not enough: financial -sector sources of central-bank independence', NBER Macroeconomics Annual, Vol. 10, 253-274.

Posen A. (1998) 'Central bank independence and disinflation credibility: a missing link?' Oxford Economic Papers, Vol. 50, 335359.

Siklos P.L.(2008) 'No single definition of central bank independence is right for all countries', European Journal of Political Economy, Vol. 24, 802-816.

Sturm, J. E. and De Haan J. (2002) 'Inflation in developing countries: does central bank independence matter? New evidence based on a new dataset', Ifo Studien, Vol. 47, 389-403.

Temple, J. (1998) 'Central bank independence and inflation: good news and bad news', Economics Letters, Vol. 61, pp. $215-219$.

Thomas, C. and Zanetti, F. (2009) 'Labour market reform and price stability: an application to the euro area', Journal of Monetary Economics, Vol. 56, 885-899.

Tsoukis, C., Agiomirgianakis, G., and Biswas, T. (eds) 2003 Aspects of Globalization: Macroeconomic and Capital Market Linkages in the Integrated World Economy, Kluwer Academic Publishers.

Visser, J. (2011) ICTWSS Database on Institutional Characteristics of Trade Unions, Wage Setting, State Intervention, and Social Pacts, Version 3.0, Amsterdam Institute for Advanced Labour Studies, University of Amsterdam.

Zellner, A. (1971) An Introduction to Bayesian Inference in Econometrics, Wiley, New York 


\section{$\underline{\text { Appendix }}$}

TABLE A Statistical properties of the variables

\begin{tabular}{|c|c|c|c|c|c|}
\hline Variable & Mean & Max & Min & St. dev. & No. of obs. \\
\hline$L C B I$ & 0.508 & 0.919 & 0.100 & 0.215 & 107 \\
\hline$G Q U A L$ & 0.806 & 1.000 & 0.440 & 0.170 & 107 \\
\hline$L I B D F$ & 0.614 & 0.997 & 0.185 & 0.198 & 107 \\
\hline$L I B D T$ & 0.694 & 0.968 & 0.370 & 0.145 & 107 \\
\hline LIBGT & 0.737 & 0.883 & 0.330 & 0.095 & 107 \\
\hline RLEND & 0.049 & 0.286 & -0.184 & 0.053 & 103 \\
\hline PROD & 0.819 & 0.992 & 0.391 & 0.135 & 104 \\
\hline$U L C M$ & 0.979 & 1.732 & 0.637 & 0.191 & 100 \\
\hline DENS & 0.395 & 0.960 & 0.082 & 0.213 & 107 \\
\hline EMPR & 0.364 & 0.695 & 0.035 & 0.165 & 91 \\
\hline ALMP & 0.006 & 0.026 & 0.003 & 0.005 & 88 \\
\hline$D E F$ & 0.024 & 0.107 & -0.120 & 0.035 & 101 \\
\hline$D E F V$ & 0.021 & 0.104 & 0.003 & 0.015 & 101 \\
\hline$N E X V$ & 0.109 & 1.507 & 0.011 & 0.204 & 97 \\
\hline OPEN & 0.406 & 1.368 & 0.090 & 0.223 & 107 \\
\hline$G D P G$ & 0.029 & 0.083 & -0.060 & 0.019 & 107 \\
\hline$I N F L$ & 0.071 & 0.454 & -0.013 & 0.094 & 107 \\
\hline$E M G$ & 0.009 & 0.044 & -0.042 & 0.014 & 107 \\
\hline GDPRES $^{a}$ & 0.039 & 1.542 & -0.898 & 0.333 & 57 \\
\hline
\end{tabular}

${ }^{a}$ Pooled sample 1991-1998, 1999-2006 (see footnote 25).

TABLE A.1 Average independence scores, 1981-1989, 1991-1998 \& 1999-2006 (CWN methodology) a,b,c

\begin{tabular}{|c|c|c|c|c|c|c|c|c|}
\hline $\mathbf{A U}$ & $\begin{array}{l}1981-1989 \\
1991-1998 \\
1999-2006\end{array}$ & $\begin{array}{l}0.614 \\
0.614 \\
0.908\end{array}$ & HU & $\begin{array}{l}1981-1989 \\
1991-1998 \\
1999-2006\end{array}$ & $\begin{array}{l}0.240 \\
0.630 \\
0.693\end{array}$ & NOR & $\begin{array}{l}1981-1989 \\
1991-1998 \\
1999-2006\end{array}$ & $\begin{array}{l}0.170 \\
0.170 \\
0.332\end{array}$ \\
\hline AUS & $\begin{array}{l}1981-1989 \\
1991-1998 \\
1999-2006\end{array}$ & $\begin{array}{l}0.363 \\
0.363 \\
0.431\end{array}$ & ICE & $\begin{array}{c}1981-1989 \\
1991-1998 \\
1999-2006\end{array}$ & $\begin{array}{l}0.344 \\
0.344 \\
0.673\end{array}$ & NZ & $\begin{array}{c}1981-1989 \\
1991-1998 \\
1999-2006\end{array}$ & $\begin{array}{l}0.243 \\
0.311 \\
0.386\end{array}$ \\
\hline BE & $\begin{array}{l}1981-1989 \\
1991-1998 \\
1999-2006\end{array}$ & $\begin{array}{l}0.173 \\
0.336 \\
0.908\end{array}$ & IR & $\begin{array}{l}1981-1989 \\
1991-1998 \\
1999-2006\end{array}$ & $\begin{array}{l}0.438 \\
0.481 \\
0.908\end{array}$ & POL & $\begin{array}{l}1981-1989 \\
1991-1998 \\
1999-2006\end{array}$ & $\begin{array}{l}0.100 \\
0.360 \\
0.919\end{array}$ \\
\hline BU & $\begin{array}{l}1981-1989 \\
1991-1998 \\
1999-2006\end{array}$ & $\begin{array}{c}- \\
0.490 \\
0.768\end{array}$ & ISR & $\begin{array}{c}1981-1989 \\
1991-1998 \\
1999-2006\end{array}$ & $\begin{array}{l}0.390 \\
0.390 \\
0.475\end{array}$ & POR & $\begin{array}{c}1981-1989 \\
1991-1998 \\
1999-2006\end{array}$ & $\begin{array}{l}0.411 \\
0.523 \\
0.908\end{array}$ \\
\hline CAN & $\begin{array}{c}1981-1989 \\
1991-1998 \\
1999-2006\end{array}$ & $\begin{array}{l}0.451 \\
0.451 \\
0.617\end{array}$ & IT & $\begin{array}{c}1981-1989 \\
1991-1998 \\
1999-2006\end{array}$ & $\begin{array}{l}0.246 \\
0.414 \\
0.908\end{array}$ & ROM & $\begin{array}{c}1981-1989 \\
1991-1998 \\
1999-2006\end{array}$ & $\begin{array}{c}- \\
0.342 \\
0.384\end{array}$ \\
\hline $\mathrm{CY}$ & $\begin{array}{l}1981-1989 \\
1991-1998 \\
1999-2006\end{array}$ & $\begin{array}{c}- \\
- \\
0.463\end{array}$ & JAP & $\begin{array}{c}1981-1989 \\
1991-1998 \\
1999-2006\end{array}$ & $\begin{array}{l}0.179 \\
0.179 \\
0.294\end{array}$ & SI & $\begin{array}{c}1981-1989 \\
1991-1998 \\
1999-2006\end{array}$ & $\begin{array}{c}- \\
0.420 \\
0.671\end{array}$ \\
\hline $\mathrm{CZ}$ & $\begin{array}{l}1981-1989 \\
1991-1998 \\
1999-2006\end{array}$ & $\begin{array}{c}- \\
0.620 \\
0.756\end{array}$ & KOR & $\begin{array}{l}1981-1989 \\
1991-1998 \\
1999-2006\end{array}$ & $\begin{array}{l}0.266 \\
0.266 \\
0.316\end{array}$ & SL & $\begin{array}{c}1981-1989 \\
1991-1998 \\
1999-2006\end{array}$ & $\begin{array}{c}- \\
0.560 \\
0.664\end{array}$ \\
\hline DEN & $\begin{array}{l}1981-1989 \\
1991-1998 \\
1999-2006\end{array}$ & $\begin{array}{l}0.500 \\
0.500 \\
0.563\end{array}$ & LAT & $\begin{array}{c}1981-1989 \\
1991-1998 \\
1999-2006\end{array}$ & $\begin{array}{c}- \\
0.491 \\
0.582\end{array}$ & SP & $\begin{array}{c}1981-1989 \\
1991-1998 \\
1999-2006\end{array}$ & $\begin{array}{l}0.231 \\
0.573 \\
0.908\end{array}$ \\
\hline DEU & $\begin{array}{c}1980-1989 \\
1991-1998 \\
1999-2006\end{array}$ & $\begin{array}{l}0.691 \\
0.741 \\
0.908\end{array}$ & LITH & $\begin{array}{c}1981-1989 \\
1991-1998 \\
1999-2006\end{array}$ & $\begin{array}{c}- \\
0.275 \\
0.812\end{array}$ & SWE & $\begin{array}{c}1981-1989 \\
1991-1998 \\
1999-2006\end{array}$ & $\begin{array}{l}0.293 \\
0.293 \\
0.388\end{array}$ \\
\hline EL & $\begin{array}{c}1981-1989 \\
1991-1998 \\
1999-2006\end{array}$ & $\begin{array}{l}0.553 \\
0.553 \\
0.908\end{array}$ & $\mathbf{L U}$ & $\begin{array}{c}1981-1989 \\
1991-1998 \\
1999-2006\end{array}$ & $\begin{array}{l}0.327 \\
0.465 \\
0.908\end{array}$ & SWIT & $\begin{array}{c}1981-1989 \\
1991-1998 \\
1999-2006\end{array}$ & $\begin{array}{l}0.640 \\
0.661 \\
0.661\end{array}$ \\
\hline EST & $\begin{array}{c}1981-1989 \\
1991-1998 \\
1999-2006\end{array}$ & $\begin{array}{c}- \\
0.783 \\
0.795\end{array}$ & MA & $\begin{array}{c}1981-1989 \\
1991-1998 \\
1999-2006\end{array}$ & $\begin{array}{l}0.440 \\
0.514 \\
0.539\end{array}$ & TU & $\begin{array}{c}1981-1989 \\
1991-1998 \\
1999-2006\end{array}$ & $\begin{array}{l}0.455 \\
0.532 \\
0.590\end{array}$ \\
\hline FIN & $\begin{array}{c}1981-1989 \\
1991-1998 \\
1999-2006\end{array}$ & $\begin{array}{l}0.279 \\
0.403 \\
0.908\end{array}$ & MEX & $\begin{array}{c}1981-1989 \\
1991-1998 \\
1999-2006\end{array}$ & $\begin{array}{l}0.342 \\
0.342 \\
0.653\end{array}$ & UK & $\begin{array}{c}1981-1989 \\
1991-1998 \\
1999-2006\end{array}$ & $\begin{array}{l}0.265 \\
0.350 \\
0.420\end{array}$ \\
\hline FR & $\begin{array}{c}1981-1989 \\
1991-1998 \\
1999-2006\end{array}$ & $\begin{array}{l}0.241 \\
0.607 \\
0.908\end{array}$ & NETH & $\begin{array}{l}1981-1989 \\
1991-1998 \\
1999-2006\end{array}$ & $\begin{array}{l}0.419 \\
0.419 \\
0.908\end{array}$ & US & $\begin{array}{c}1981-1989 \\
1991-1998 \\
1999-2006\end{array}$ & $\begin{array}{l}0.483 \\
0.483 \\
0.559\end{array}$ \\
\hline
\end{tabular}




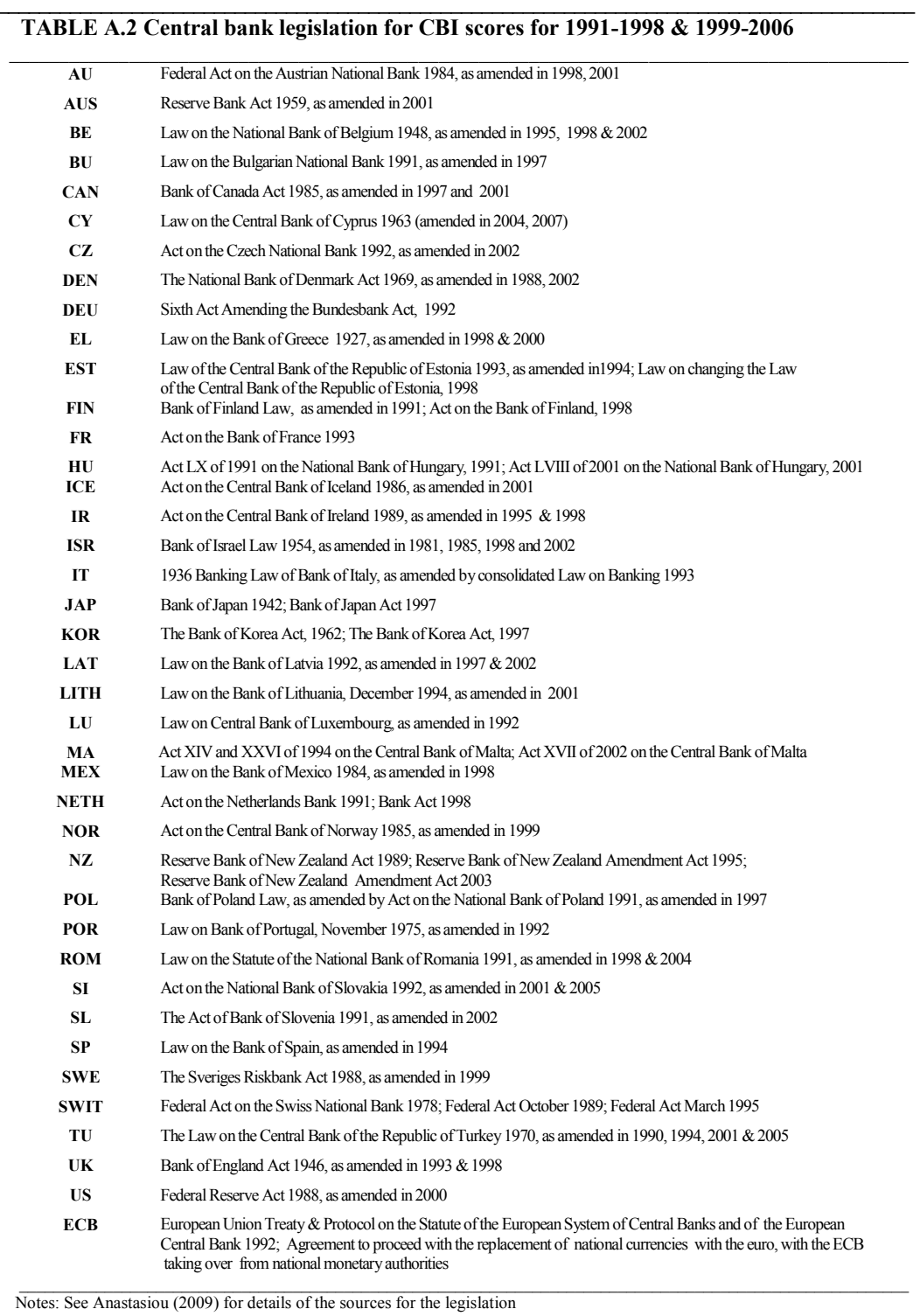


TABLE 1.1: Regression results explaining inflation performance, pooled sample 1981-2006

\begin{tabular}{|c|c|c|c|c|c|c|c|c|c|c|c|c|c|c|c|c|c|c|}
\hline \multicolumn{19}{|c|}{ Dependent Variable: Inflation, $I_{N F L}{ }^{\text {a, b }}$} \\
\hline & (a) & (b) & _(c) & (d) & (e) & (f) & (g) & (h) & (i) & (j) & $(\mathbf{k})$ & (l) & -(m) & (n) & (o) & (p) & (q) & (r) \\
\hline \multicolumn{19}{|l|}{$\begin{array}{l}\text { Explanatory } \\
\text { variables }\end{array}$} \\
\hline LCBI & $\begin{array}{l}-0.122^{\star \star \star} \\
(0.032)\end{array}$ & $\begin{array}{l}-0.094^{* \star} \\
(0.031)\end{array}$ & $\begin{array}{l}-0.067^{\star \star} \\
(0.032)\end{array}$ & $\begin{array}{l}-0.069^{\star *} \\
(0.031)\end{array}$ & $\begin{array}{l}-0.052 \\
(0.032)\end{array}$ & $\begin{array}{l}-0.051^{* *} \\
(0.026)\end{array}$ & $\begin{array}{c}-0.019 \\
(0.030)\end{array}$ & $\begin{array}{l}-0.018 \\
(0.028)\end{array}$ & $\begin{array}{l}-0.012 \\
(0.028)\end{array}$ & $\begin{array}{c}-0.002 \\
(0.030)\end{array}$ & $\begin{array}{l}-0.073^{* * *} \\
(0.021)\end{array}$ & $\begin{array}{l}-0.042^{\star \star \star} \\
(0.016)\end{array}$ & $\begin{array}{l}-0.027 \\
(0.018)\end{array}$ & $\begin{array}{c}-0.023 \\
(0.017)\end{array}$ & $\begin{array}{l}-0.028 \\
(0.020)\end{array}$ & $\begin{array}{l}-0.046^{* *} \\
(0.024)\end{array}$ & $\begin{array}{l}-0.035^{\star \star} \\
(0.016)\end{array}$ & $\begin{array}{l}-0.033^{* *} \\
(0.015)\end{array}$ \\
\hline GQUAL & & $\begin{array}{l}-0.308^{\star * *} \\
(0.057)\end{array}$ & $\begin{array}{l}-0.220^{* * *} \\
(0.059)\end{array}$ & $\begin{array}{l}-0.263^{* * *} \\
(0.058)\end{array}$ & $\begin{array}{l}-0.227^{* \star *} \\
(0.056)\end{array}$ & $\begin{array}{l}-0.273^{\star * \star} \\
(0.049)\end{array}$ & $\begin{array}{l}-0.206^{* * *} \\
(0.053)\end{array}$ & $\begin{array}{l}-0.254^{* * *} \\
(0.060)\end{array}$ & $\begin{array}{l}-0.320^{* * *} \\
(0.055)\end{array}$ & $\begin{array}{l}-0.274^{* * *} \\
(0.049)\end{array}$ & $\begin{array}{l}-0.277^{\star \star *} \\
(0.056)\end{array}$ & $\begin{array}{l}-0.157^{\star \star \star *} \\
(0.030)\end{array}$ & $\begin{array}{l}-0.126^{* * *} \\
(0.036)\end{array}$ & $\begin{array}{l}-0.141^{* \star *} \\
(0.033)\end{array}$ & $\begin{array}{l}-0.115^{* * *} \\
(0.042)\end{array}$ & & $\begin{array}{l}-0.105^{* * *} \\
(0.030)\end{array}$ & $\begin{array}{l}-0.099^{* * *} \\
(0.030)\end{array}$ \\
\hline LIBDF & & & & $\begin{array}{l}-0.092^{* \star} \\
(0.043)\end{array}$ & & & & & $\begin{array}{l}-0.072^{*} \\
(0.042)\end{array}$ & & & & & & & & & \\
\hline RLEND & & & & $\begin{array}{l}0.107 \\
(0.323)\end{array}$ & & & & & $\begin{array}{l}0.172 \\
(0.270)\end{array}$ & & & & & & $\begin{array}{l}-0.264 \\
(0.176)\end{array}$ & $\begin{array}{l}-0.269 \\
(0.328)\end{array}$ & $\begin{array}{l}-0.140 \\
(0.173)\end{array}$ & $\begin{array}{l}-0.206 \\
(0.175)\end{array}$ \\
\hline LIBGT & & & $\begin{array}{l}-0.327^{\star \star *} \\
(0.107)\end{array}$ & & & & $\begin{array}{l}-0.300^{\star * *} \\
(0.102)\end{array}$ & $\begin{array}{l}-0.248^{\star * *} \\
(0.102)\end{array}$ & & & & & $\begin{array}{c}-0.155^{\star} \\
(0.085)\end{array}$ & & $\begin{array}{l}-0.159^{*} \\
(0.095)\end{array}$ & & & \\
\hline LIBDT & & & & & $\begin{array}{l}-0.196^{\star * \star} \\
(0.072)\end{array}$ & & & & & $\begin{array}{c}-0.157^{\star \star} \\
(0.069)\end{array}$ & & & & $\begin{array}{c}-0.062^{*} \\
(0.032)\end{array}$ & & & & \\
\hline PROD & & & & & & $\begin{array}{l}-0.215^{* * *} \\
(0.065)\end{array}$ & $\begin{array}{l}-0.177^{\star * *} \\
(0.062)\end{array}$ & $\begin{array}{l}-0.158^{\star \star} \\
(0.063)\end{array}$ & $\begin{array}{l}-0.145^{\star \star} \\
(0.071)\end{array}$ & $\begin{array}{c}-0.119^{*} \\
(0.067)\end{array}$ & & & & & & & & \\
\hline DENS & & & & & & & & $\begin{array}{l}0.075^{*} \\
(0.041)\end{array}$ & $\begin{array}{l}0.123^{\star \star \star} \\
(0.042)\end{array}$ & $\begin{array}{l}0.118^{\star \star \star} \\
(0.042)\end{array}$ & $\begin{array}{l}0.096^{\star * *} \\
(0.031)\end{array}$ & $\begin{array}{l}0.080^{* \star *} \\
(0.019)\end{array}$ & $\begin{array}{l}0.071^{\star \star \star} \\
(0.020)\end{array}$ & $\begin{array}{l}0.084^{\star * *} \\
(0.019)\end{array}$ & $\begin{array}{l}0.070^{\star \star \star *} \\
(0.018)\end{array}$ & & 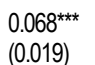 & $\begin{array}{l}0.069^{\star \star *} \\
(0.018)\end{array}$ \\
\hline EMPR & & & & & & & & & & & $\begin{array}{r}0.010 \\
(0.021)\end{array}$ & $\begin{array}{l}0.008 \\
(0.019)\end{array}$ & $\begin{array}{l}0.008 \\
(0.017)\end{array}$ & $\begin{array}{l}0.007 \\
(0.018)\end{array}$ & $\begin{array}{l}0.017 \\
(0.020)\end{array}$ & & $\begin{array}{l}0.010 \\
(0.018)\end{array}$ & $\begin{array}{l}0.010 \\
(0.017)\end{array}$ \\
\hline ALMP & & & & & & & & & & & & $\begin{array}{l}-1.856^{* * *} \\
(0644)\end{array}$ & $-1.346^{* *}$ & $-1.511^{\text {** }}$ & $\begin{array}{l}-1.268^{* *} \\
(0.723)\end{array}$ & & $\begin{array}{l}-1.774^{* * *} \\
(0674)\end{array}$ & $\begin{array}{l}-1.718^{* * *} \\
(0648)\end{array}$ \\
\hline DEF & & & & & & & & & & & & & & & $0.181^{*}$ & $0.170^{*}$ & & $0.145^{*}$ \\
\hline NEXV & & & & & & & & & & & & & & & & $0.135^{\star \star \star}$ & $0.076^{* *}$ & $0.072^{* *}$ \\
\hline & & & & & & & & & & & & & & & & $(0.041)$ & $(0.031)$ & $(0.033)$ \\
\hline OPEN & & & & & & & & & & & & & & & & $\begin{array}{l}0.039^{* *} \\
(0.020)\end{array}$ & $\begin{array}{l}0.011 \\
(0.013)\end{array}$ & $\begin{array}{l}0.012 \\
(0.013)\end{array}$ \\
\hline \multirow{2}{*}{$\begin{array}{l}\text { No. of obs. } \\
\text { R-squared } \\
\text { (adj) }\end{array}$} & 107 & 107 & 107 & 103 & 107 & 104 & 104 & 104 & 101 & 104 & 91 & 88 & 88 & 88 & 85 & 93 & 85 & 85 \\
\hline & 0.036 & 0.308 & 0.405 & 0.324 & 0.382 & 0.409 & 0.462 & 0.479 & 0.459 & 0.471 & 0.343 & 0.368 & 0.408 & 0.387 & 0.437 & 0.299 & 0.472 & 0.482 \\
\hline
\end{tabular}

Notes: ${ }^{\mathrm{a}} I N F L$ is measured by the modified inflation rate $\frac{\pi}{1+\pi}$, where $\pi$ is the log difference of GDP deflator; ${ }^{\mathrm{b}}$ White-heteroskedasticity-consistent standard errors in parenthesis, OLS $(* * *, * *$ and $*$ indicate significance at $1 \%, 5 \%, 10 \%$ level respectively, constant not reported). 
TABLE 2.1 Regression results explaining employment growth, pooled sample 1981-2006

\begin{tabular}{|c|c|c|c|c|c|c|c|c|c|c|c|c|c|c|c|c|}
\hline \multicolumn{17}{|c|}{ Dependent Variable: Employment growth, $E M G^{\text {a, b }}$} \\
\hline & (a) & (b) & (c) & _(d) & (e) & (f) & _(g) & (h) & (i) & _(j) & -(k) & (l) & _(m) & (n) & -(o) & -(p) \\
\hline \multicolumn{17}{|l|}{$\begin{array}{l}\text { Explanatory } \\
\text { Variables }\end{array}$} \\
\hline LCBI & $\begin{array}{l}0.010^{* *} \\
(0.005)\end{array}$ & $\begin{array}{l}-0.006 \\
(0.005)\end{array}$ & $\begin{array}{l}-0.011^{*} \\
(0.006)\end{array}$ & $\begin{array}{l}-0.012^{* *} \\
(0.006)\end{array}$ & $\begin{array}{l}-0.010^{*} \\
(0.006)\end{array}$ & $\begin{array}{l}-0.013^{* *} \\
(0.006)\end{array}$ & $\begin{array}{l}-0.007 \\
(0.005)\end{array}$ & $\begin{array}{l}-0.009 \\
(0.006)\end{array}$ & $\begin{array}{l}-0.002 \\
(0.005)\end{array}$ & $\begin{array}{l}-0.006 \\
(0.005)\end{array}$ & $\begin{array}{l}-0.004 \\
(0.005)\end{array}$ & $\begin{array}{l}-0.003 \\
(0.004)\end{array}$ & $\begin{array}{l}-0.005 \\
(0.004)\end{array}$ & $\begin{array}{l}-0.006 \\
(0.004)\end{array}$ & $\begin{array}{l}-0.009^{* *} \\
(0.004)\end{array}$ & $\begin{array}{l}-0.011^{* *} \\
(0.005)\end{array}$ \\
\hline GDPG & & $\begin{array}{l}0.370^{\star \star \star} \\
(0.087)\end{array}$ & $\begin{array}{l}0.351^{\star \star \star} \\
(0.083)\end{array}$ & $\begin{array}{l}0.354^{\star \star *} \\
(0.086)\end{array}$ & $\begin{array}{l}0.329^{\star \star \star} \\
(0.091)\end{array}$ & $\begin{array}{l}0.301^{* \star *} \\
(0.100)\end{array}$ & $\begin{array}{l}0.337^{\star \star \star *} \\
(0.092)\end{array}$ & $\begin{array}{l}0.311^{\star \star *} \\
(0.099)\end{array}$ & $\begin{array}{l}0.450^{* * \star} \\
(0.096)\end{array}$ & $\begin{array}{l}0.426^{* \star \star \star} \\
(0.096)\end{array}$ & $\begin{array}{l}0.392^{\star \star \star} \\
(0.091)\end{array}$ & $\begin{array}{l}0.356^{* * \star} \\
(0.089)\end{array}$ & $\begin{array}{l}0.339^{* \star \star} \\
(0.091)\end{array}$ & $\begin{array}{l}0.342^{\star \star \star} \\
(0.078)\end{array}$ & $\begin{array}{l}0.362^{* \star \star} \\
(0.082)\end{array}$ & $\begin{array}{l}0.366^{\star \star \star} \\
(0.079)\end{array}$ \\
\hline LIBDF & & & $\begin{array}{l}0.013^{\star \star} \\
(0.006)\end{array}$ & & & & & & & & & & & & & \\
\hline RLEND & & & & & & & & & & & & & & $\begin{array}{l}-0.039 \\
(0.043)\end{array}$ & $\begin{array}{l}-0.060 \\
(0.048)\end{array}$ & $\begin{array}{l}-0.062 \\
(0.049)\end{array}$ \\
\hline LIBGT & & & & & & & $\begin{array}{l}0.021^{\star \star *} \\
(0.000)\end{array}$ & $\begin{array}{l}0.027^{* * *} \\
(0.010)\end{array}$ & & & & & & & & \\
\hline LIBDT & & & & $\begin{array}{l}0.018^{* *} \\
(0.008)\end{array}$ & $\begin{array}{l}0.018^{* *} \\
(0.008)\end{array}$ & $\begin{array}{l}0.021^{* *} \\
(0.009)\end{array}$ & & & & & & & & & & \\
\hline ULCM & & & & & $\begin{array}{l}-0.014^{* *} \\
(0.006)\end{array}$ & $\begin{array}{l}-0.013^{* *} \\
(0.006)\end{array}$ & $\begin{array}{l}-0.014^{* \star *} \\
(0.005)\end{array}$ & $\begin{array}{l}-0.013^{* *} \\
(0.005)\end{array}$ & $\begin{array}{l}-0.017^{\star \star \star} \\
(0.006)\end{array}$ & $\begin{array}{l}-0.016^{* * *} \\
(0.006)\end{array}$ & & $\begin{array}{l}-0.018^{* * *} \\
(0.006)\end{array}$ & $\begin{array}{l}-0.017^{* * *} \\
(0.006)\end{array}$ & $\begin{array}{l}-0.013^{* *} \\
(0.006)\end{array}$ & $\begin{array}{l}-0.015^{\star \star *} \\
(0.006)\end{array}$ & $\begin{array}{l}-0.016^{* * *} \\
(0.006)\end{array}$ \\
\hline GQUAL & & & & & & & & & & & $\begin{array}{l}0.022^{\star *} \\
(0.010)\end{array}$ & $\begin{array}{l}0.022^{* * *} \\
(0.006)\end{array}$ & $\begin{array}{l}0.029^{* k *} \\
(0.007)\end{array}$ & & & \\
\hline DENS & & & & & & & & & & & & & $\begin{array}{l}-0.013^{* *} \\
(0.005)\end{array}$ & & $\begin{array}{l}-0.015^{\star \star *} \\
(0.005)\end{array}$ & $\begin{array}{l}-0.010^{* *} \\
(0.005)\end{array}$ \\
\hline EMPR & & & & & & & & & & & & & & $\begin{array}{c}-0.010 \\
(0.006)\end{array}$ & $\begin{array}{c}-0.009 \\
(0.006)\end{array}$ & $\begin{array}{l}-0.010 \\
(0.006)\end{array}$ \\
\hline ALMP & & & & & & & & & & & & & & & $\begin{array}{l}0.604^{* *} \\
(0.280)\end{array}$ & $\begin{array}{l}0.586^{\star *} \\
(0.276)\end{array}$ \\
\hline DEFV & & & & & & $\begin{array}{l}-0.178^{*} \\
(0.097)\end{array}$ & & $\begin{array}{l}-0.171^{*} \\
(0.095)\end{array}$ & & $\begin{array}{l}-0.202^{* *} \\
(0.085)\end{array}$ & & & & & & $\begin{array}{l}-0.169^{\star \star \star} \\
(0.053)\end{array}$ \\
\hline$N E X V$ & & & & & & & & & $\begin{array}{l}-0.004 \\
(0.005)\end{array}$ & $\begin{array}{l}-0.002 \\
(0.005)\end{array}$ & & & & & & \\
\hline OPEN & & & & & & & & & $\begin{array}{l}-0.014^{* *} \\
(0.006)\end{array}$ & $\begin{array}{l}-0.011^{*} \\
(0.006)\end{array}$ & & & & & & \\
\hline $\begin{array}{l}\text { No. of } \\
\text { obs. }\end{array}$ & 107 & 107 & 107 & 107 & 100 & 97 & 100 & 97 & 95 & 94 & 107 & 100 & 100 & 86 & 83 & 83 \\
\hline $\begin{array}{c}R \text {-squared } \\
\text { (adj) }\end{array}$ & 0.022 & 0.223 & 0.240 & 0.242 & 0.257 & 0.278 & 0.251 & 0.270 & 0.256 & 0.287 & 0.280 & 0.331 & 0.356 & 0.300 & 0.311 & 0.343 \\
\hline
\end{tabular}

Notes: ${ }^{\mathrm{a}} E M G$ is measured by the log difference of total employment; ${ }^{\mathrm{b}}$ White-heteroskedasticity-consistent standard errors in parenthesis, OLS $(* * *, * *$ and $*$ indicate significance at $1 \%, 5 \%$ and $10 \%$ level respectively, constant not reported). 
TABLE 3.1 Regression results explaining short-run output response to real shocks, pooled sample 1991-2006

\begin{tabular}{|c|c|c|c|c|c|c|c|c|c|c|}
\hline \multicolumn{11}{|c|}{ Dependent Variable: GDPRESP ${ }^{\mathrm{a}, \mathrm{b}}$} \\
\hline \multicolumn{11}{|l|}{$\begin{array}{c}\text { Explanatory } \\
\text { variables }\end{array}$} \\
\hline LCBI & $\begin{array}{l}0.411^{* * *} \\
(0.159)\end{array}$ & $\begin{array}{l}0.402^{* \star *} \\
(0.151)\end{array}$ & $\begin{array}{l}0.413^{* \star *} \\
(0.127)\end{array}$ & $\begin{array}{l}0.303^{* * *} \\
(0.109)\end{array}$ & $\begin{array}{l}0.391^{* * *} \\
(0.121)\end{array}$ & $\begin{array}{l}0.476^{* * *} \\
(0.131)\end{array}$ & $\begin{array}{l}0.323^{* *} \\
(0.153)\end{array}$ & $\begin{array}{l}0.426^{* * *} \\
(0.149)\end{array}$ & $\begin{array}{l}0.418^{* * *} \\
(0.118)\end{array}$ & $\begin{array}{l}0.474^{\star * *} \\
(0.128)\end{array}$ \\
\hline GQUAL & & $\begin{array}{c}-0.309^{* *} \\
(0.134)\end{array}$ & $\begin{array}{c}-0.348^{* \star *} \\
(0.134)\end{array}$ & $\begin{array}{c}-0.532^{* *} \\
(0.26)\end{array}$ & $\begin{array}{c}-0.375^{\star \star \star} \\
(0.118)\end{array}$ & $\begin{array}{c}-0.323^{\star \star *} \\
(0.114)\end{array}$ & $\begin{array}{c}-0.488^{* \star *} \\
(0.166)\end{array}$ & $\begin{array}{c}-0.283^{\star *} \\
(0.131)\end{array}$ & $\begin{array}{c}-0.326^{\star * *} \\
(0.110)\end{array}$ & $\begin{array}{c}-0.300^{\star * *} \\
(0.106)\end{array}$ \\
\hline DENS & & & $\begin{array}{c}0.072 \\
(0327)\end{array}$ & & $0.556^{*}$ & $0.568^{* *}$ & $0.472^{*}$ & & $0.540^{*}$ & $0.550^{* *}$ \\
\hline EMPR & & & & $\begin{array}{l}-0.382^{*} \\
(0.212)\end{array}$ & & $\begin{array}{l}-0.321^{*} \\
(0.192)\end{array}$ & $\begin{array}{l}(0.272) \\
-0.290^{*} \\
(0.172)\end{array}$ & & & $\begin{array}{l}-0.223 \\
(0.190)\end{array}$ \\
\hline ALMP & & & & & $\begin{array}{l}-0.156 \\
(0.109)\end{array}$ & $\begin{array}{l}-0.144 \\
(0.103)\end{array}$ & $\begin{array}{l}-0.167^{\star} \\
(0.096)\end{array}$ & & $\begin{array}{l}-0.171^{*} \\
(0.101)\end{array}$ & $\begin{array}{l}-0.162^{*} \\
(0.096)\end{array}$ \\
\hline LIBDF & & & & & & & 0.408 & & & \\
\hline DEF & & & & & & & & $\begin{array}{c}-1.937^{\star \star \star} \\
(0.605)\end{array}$ & $\begin{array}{c}-2.129^{\star \star *} \\
(0.758)\end{array}$ & $\begin{array}{c}-1.883^{\star \star \star} \\
(0.662)\end{array}$ \\
\hline No. of obs: & 57 & 57 & 57 & 50 & 50 & 50 & 50 & 57 & 50 & 50 \\
\hline R-squared (adj) & 0.054 & 0.082 & 0.067 & 0.106 & 0.150 & 0.175 & 0.207 & 0.111 & 0.222 & 0.225 \\
\hline
\end{tabular}

Notes: ${ }^{\mathrm{a}}$ GDPRES is defined as the percentage deviation of output from trend to the standard deviation of real effective exchange rates; ${ }^{\mathrm{b}}$ White-heteroskedasticity-consistent standard errors in parenthesis, OLS ( $* * *, * *$ and $*$ indicate significance at $1 \%, 5 \%$ and $10 \%$ level respectively). 
TABLE 1.2 Parameter point estimates for inflation obtained from 10,000 Gibbs-Sampler iterations and "burn in" phase of 500 iterations (pooled sample, 1981-2006)

\begin{tabular}{|c|c|c|c|c|c|c|c|c|c|c|c|c|}
\hline \multicolumn{13}{|c|}{ Dependent Variable: Inflation, $I N F^{\mathrm{a}, \mathrm{b}}$} \\
\hline & (i) & _(ii) & _(iii) & (iv) & _(v) & (vi) & _(vii) & _(viii) & $(\mathbf{i x})$ & $(\mathbf{x})$ & -(xi) & (xii) \\
\hline \multicolumn{13}{|l|}{$\begin{array}{c}\text { Explanatory } \\
\text { variables }\end{array}$} \\
\hline LCBI & $\begin{array}{c}-0.111 \\
(0.001) \\
{[-0.114,-0.108]}\end{array}$ & $\begin{array}{c}-0.067 \\
(0.002) \\
{[-0.070,-0.063]}\end{array}$ & $\begin{array}{c}-0.077 \\
(0.002) \\
{[-0.081,-0.073]}\end{array}$ & $\begin{array}{c}-0.047 \\
(0.002) \\
{[-0.052,-0.042]}\end{array}$ & $\begin{array}{c}-0.030 \\
(0.002) \\
{[-0.034,-0.026]}\end{array}$ & $\begin{array}{c}-0.021 \\
(0.002) \\
{[-0.024,-0.018]}\end{array}$ & $\begin{array}{c}-0.015 \\
(0.001) \\
{[-0.018,-0.011]}\end{array}$ & $\begin{array}{c}-0.030 \\
(0.001) \\
{[-0.032,-0.027]}\end{array}$ & $\begin{array}{c}-0.026 \\
(0.001) \\
{[-0.028,-0.025]}\end{array}$ & $\begin{array}{c}-0.022 \\
(0.001) \\
{[-0.024,-0.019]}\end{array}$ & $\begin{array}{c}-0.034 \\
(0.002) \\
{[-0.037,-0.030]}\end{array}$ & $\begin{array}{c}-0.030 \\
(0.002) \\
{[-0.034,-0.027]}\end{array}$ \\
\hline GQUAL & $\begin{array}{c}-0.251 \\
(0.002) \\
{[-0.256-0.246]}\end{array}$ & $\begin{array}{c}-0.212 \\
(0.003) \\
{[-0.217-0.206]}\end{array}$ & $\begin{array}{c}-0.257 \\
(0.003) \\
{[-0.263,-0.252}\end{array}$ & $\begin{array}{c}-0.190 \\
(0.003) \\
{[-0.196,-0.184]}\end{array}$ & $\begin{array}{c}-0.272 \\
(0.003) \\
{[-0.279,-0.265]}\end{array}$ & $\begin{array}{c}-0.331 \\
(0.002) \\
{[-0.335,-0.326]}\end{array}$ & $\begin{array}{c}-0.296 \\
(0.003) \\
{[-0.301,-0.290]}\end{array}$ & $\begin{array}{c}-0.147 \\
(0.007) \\
{[-0.161,-0.134]}\end{array}$ & $\begin{array}{c}-0.164 \\
(0.008) \\
{[-0.180,-0.149}\end{array}$ & $\begin{array}{c}-0.121 \\
(0.008) \\
-0.137,-0.104]\end{array}$ & $\begin{array}{c}-0.110 \\
(0.010) \\
{[-0.131,-0.089]}\end{array}$ & $\begin{array}{c}-0.105 \\
(0.010) \\
{[-0.125,-0.084]}\end{array}$ \\
\hline LIBDF & & & $\begin{array}{c}{[-0.20,-0.20} \\
-0.080 \\
(0.002) \\
{[-0.083,-0.076]}\end{array}$ & & & $\begin{array}{c}{[-0.084} \\
(0.002) \\
{[-0.089,-0.080]}\end{array}$ & & & & & & \\
\hline RLEND & & & $\begin{array}{l}0.259 \\
(0.018)\end{array}$ & & & $\begin{array}{l}0.259 \\
(0.014)\end{array}$ & & & & $\begin{array}{l}-0.328 \\
(0.016)\end{array}$ & $\begin{array}{l}-0.226 \\
(0.019)\end{array}$ & $\begin{array}{l}-0.288 \\
(0.019)\end{array}$ \\
\hline & & & {$[0.224,0.293]$} & & & {$[0.231,0.286]$} & & & & {$[-0.359,-0.297]$} & {$[-0.265,-0.189]$} & {$[-0.325,-0.251]$} \\
\hline LIBGT & & $\begin{array}{c}-0.312 \\
(0.008) \\
{[-0.327,-0.297]}\end{array}$ & & & $\begin{array}{c}-0.260 \\
(0.009) \\
{[-0.279,-0.242]}\end{array}$ & & & $\begin{array}{c}-0.146 \\
(0.008) \\
{[-0.163,-0.130]}\end{array}$ & & $\begin{array}{c}-0.176 \\
(0.015) \\
{[-0.204,-0.147]}\end{array}$ & & \\
\hline LIBDT & & & & $\begin{array}{c}-0.170 \\
(0.005) \\
{[-0.180,-0.160]}\end{array}$ & & & $\begin{array}{c}-0.156 \\
(0.005) \\
{[-0.165,-0.147]}\end{array}$ & & $\begin{array}{c}-0.054 \\
(0.005) \\
{[-0.063,-0.044]}\end{array}$ & & & \\
\hline PROD & & & & & $\begin{array}{c}-0.082 \\
(0.004) \\
{[-0.089,-0.075]}\end{array}$ & $\begin{array}{c}-0.070 \\
(0.004) \\
{[-0.079,-0.061]}\end{array}$ & $\begin{array}{c}-0.047 \\
(0.004) \\
{[-0.055,-0.038]}\end{array}$ & & & & & \\
\hline DENS & & & & & $\begin{array}{c}0.111 \\
(0.002) \\
{[0.107,0.115]}\end{array}$ & $\begin{array}{c}0.158 \\
(0.002) \\
{[0.155,0.161]}\end{array}$ & $\begin{array}{c}0.157 \\
(0.002) \\
{[0.154,0.160]}\end{array}$ & $\begin{array}{c}0.075 \\
(0.005) \\
{[0.064,0.085]}\end{array}$ & $\begin{array}{c}0.086 \\
(0.005) \\
{[0.077,0.096]}\end{array}$ & $\begin{array}{c}0.068 \\
(0.006) \\
{[0.055,0.080]}\end{array}$ & $\begin{array}{c}0.069 \\
(0.005) \\
{[0.058,0.079]}\end{array}$ & $\begin{array}{c}0.071 \\
(0.005) \\
{[0.060,0.081]}\end{array}$ \\
\hline EMPR & & & & & & & & $\begin{array}{c}0.006 \\
(0.003) \\
{[-0.001,0.013]}\end{array}$ & $\begin{array}{c}0.005 \\
(0.004) \\
{[-0.002,0.012]}\end{array}$ & $\begin{array}{c}0.015 \\
(0.005) \\
{[0.005,0.025]}\end{array}$ & $\begin{array}{c}0.008 \\
(0.005) \\
{[-0.001,0.018]}\end{array}$ & $\begin{array}{c}0.012 \\
(0.005) \\
{[0.003,0.021]}\end{array}$ \\
\hline ALMP & & & & & & & & $\begin{array}{c}-1.484 \\
(0.577) \\
{[-2.617,-0.342]}\end{array}$ & $\begin{array}{c}-1.580 \\
(0.600) \\
{[-2.756,-0.401]}\end{array}$ & $\begin{array}{c}-1.275 \\
(0.620) \\
{[-2.515,-0.035]}\end{array}$ & $\begin{array}{c}-1.788 \\
(0.646) \\
{[-3.076,-0.505]}\end{array}$ & $\begin{array}{c}-1.891 \\
(0.639) \\
{[-3.151,-0.628]}\end{array}$ \\
\hline DEF & & & & & & & & & & $\begin{array}{c}0.199 \\
(0.007) \\
{[0.185,0.212]}\end{array}$ & & $\begin{array}{c}0.154 \\
(0.008) \\
{[0.139,0.170]}\end{array}$ \\
\hline NEXV & & & & & & & & & & & $\begin{array}{c}0.065 \\
(0.001) \\
{[0.063 .0 .066]}\end{array}$ & $\begin{array}{c}0.058 \\
(0001) \\
{[0.056 .00601}\end{array}$ \\
\hline OPEN & & & & & & & & & & & $\begin{array}{c}0.012 \\
(0.002) \\
{[0.008,0.016]}\end{array}$ & $\begin{array}{c}0.009 \\
(0.002) \\
{[0.005,0.013]}\end{array}$ \\
\hline
\end{tabular}

No. of

$107-107$

103

107

104

101

104

88

88

85

85

85

Notes: ${ }^{a}$ See Table 1.1.; ${ }^{b} 95 \%$ HPDIs in squared brackets, standard deviation in parenthesis, constant not reported. 
TABLE 1.2 Parameter point estimates for employment growth obtained from 10,000 Gibbs-Sampler iterations and "burn in" phase of 500 iterations (pooled sample, 1981-2006)

\begin{tabular}{|c|c|c|c|c|c|c|c|c|c|c|c|}
\hline \multicolumn{12}{|c|}{ Dependent Variable: Employment growth, $E M G^{\text {a, b }}$} \\
\hline \multirow{2}{*}{\multicolumn{12}{|c|}{ Explanatory }} \\
\hline & & & & & & & & & & & \\
\hline \multirow{2}{*}{ LCBI } & -0.006 & -0.010 & -0.009 & -0.012 & -0.007 & -0.009 & -0.006 & -0.004 & -0.003 & -0.009 & -0.011 \\
\hline & {$[-0.006,-0.006]$} & {$[-0.010,-0.010]$} & {$[-0.009,-0.009]$} & {$[-0.012,-0.012]$} & {$[-0.007,-0.006]$} & {$[-0.009,-0.009]$} & {$[-0.006,-0.006]$} & {$[-0.004,-0.004]$} & {$[-0.003,0.003]$} & {$[-0.010,-0.009]$} & {$[-0.011,-0.011]$} \\
\hline \multirow[t]{2}{*}{ GDPG } & $\begin{array}{l}0.380^{\star * *} \\
(0.004)\end{array}$ & $\begin{array}{l}0.365 \\
(0.004)\end{array}$ & $\begin{array}{l}0.335 \\
(0.003)\end{array}$ & $\begin{array}{l}0.304 \\
(0.004)\end{array}$ & $\begin{array}{c}0.339 \\
(0.003)\end{array}$ & $\begin{array}{c}0.312 \\
(0.004)\end{array}$ & $\begin{array}{c}0.419 \\
(0.005)\end{array}$ & $\begin{array}{l}0.359 \\
(0.003)\end{array}$ & $\begin{array}{c}0.356 \\
(0.003)\end{array}$ & $\begin{array}{c}0.420 \\
(0.004)\end{array}$ & $\begin{array}{c}0.414 \\
(0.004)\end{array}$ \\
\hline & {$[0.372,0.388]$} & {$[0.357,0.373]$} & {$[0.328,0.342]$} & {$[0.297,0.311]$} & {$[0.332,0.346]$} & {$[0.305,0319]$} & {$[0.410,0.428]$} & {$[0.353,0.365]$} & {$[0.350,0.362]$} & {$[0.412,0.429]$} & {$[0.405,0.422]$} \\
\hline RLEND & & & & & & & & & & $\begin{array}{c}-0.051 \\
(0.002) \\
{[-0.055,-0.047]}\end{array}$ & $\begin{array}{c}-0.053 \\
(0.002) \\
{[-0.057,-0.048]}\end{array}$ \\
\hline \multirow[t]{2}{*}{ LIBDT } & & $\begin{array}{c}0.014 \\
(0.000)\end{array}$ & $\begin{array}{c}0.013 \\
(0.000)\end{array}$ & $\begin{array}{c}0.016 \\
(0.000)\end{array}$ & & & & & & & \\
\hline & & {$[0.014,0.014]$} & {$[0.013,0.013]$} & {$[0.015,0.016]$} & & & & & & & \\
\hline \multirow[t]{2}{*}{ LIBGT } & & & & & -0.015 & -0.017 & & & & & \\
\hline & & & & & $\begin{array}{c}(0.000) \\
{[-0.14-00151}\end{array}$ & $\begin{array}{c}(0.000) \\
0-0.17-00181\end{array}$ & & & & & \\
\hline \multirow{3}{*}{ ULCM } & & & -0.015 & -0.013 & -0.014 & -0.012 & -0.013 & -0.017 & -0.013 & -0.012 & -0.012 \\
\hline & & & $(0.000)$ & $(0.000)$ & $(0.000)$ & $(0.000)$ & $(0.000)$ & $(0.000)$ & $(0.000)$ & $(0.000)$ & $(0.000)$ \\
\hline & & & {$[-0.015,-0.015]$} & {$[-0.012,-0.012]$} & {$[-0.015,0.014]$} & {$[-0.012,-0.012]$} & {$[-0.013,-0.013]$} & {$[-0.017,-0.017]$} & {$[-0.014,-0.013]$} & {$[-0.012,-0.011]$} & {$[-0.012,-0.012]$} \\
\hline GQUAL & & & & & & & & 0.020 & 0.032 & & \\
\hline \multirow[t]{3}{*}{ DENS } & & & & & & & & & -0.014 & -0.013 & -0.009 \\
\hline & & & & & & & & & $(0.000)$ & $(0.001)$ & $(0.001)$ \\
\hline & & & & & & & & & {$[-0.014,-0.014]$} & {$[-0.014,-0.012]$} & {$[-0.010,-0.007]$} \\
\hline \multirow[t]{3}{*}{ EMPR } & & & & & & & & & & -0.013 & -0.013 \\
\hline & & & & & & & & & & $(0.000)$ & $(0.000)$ \\
\hline & & & & & & & & & & {$[-0.013,-0.013]$} & {$[-0.013,-0.013]$} \\
\hline \multirow[t]{3}{*}{ ALMP } & & & & & & & & & & 0.595 & 0.551 \\
\hline & & & & & & & & & & $(0.049)$ & $(0.048)$ \\
\hline & & & & & & & & & & {$[0.498,0.691]$} & {$[0.456,0.645]$} \\
\hline \multirow[t]{3}{*}{ DEFV } & & & & -0.189 & & -0.173 & -0.194 & & & & -0.163 \\
\hline & & & & $(0.007)$ & & $(0.007)$ & $(0.008)$ & & & & $(0.005)$ \\
\hline & & & & {$[-0.203,-0.174]$} & & {$[-0.188,-0.159]$} & {$[-0.209,-0.179]$} & & & & {$[-0.173,-0.152]$} \\
\hline \multirow[t]{3}{*}{ NEXV } & & & & & & & 0.000 & & & & \\
\hline & & & & & & & $(0.000)$ & & & & \\
\hline & & & & & & & {$[0.000,0.000]$} & & & & \\
\hline \multirow[t]{3}{*}{ OPEN } & & & & & & & -0.012 & & & & \\
\hline & & & & & & & $(0.000)$ & & & & \\
\hline & & & & & & & {$[-0.012,-0.012]$} & & & & \\
\hline $\begin{array}{l}\text { No. of } \\
\text { obs. }\end{array}$ & 107 & 107 & 100 & 97 & 100 & 97 & 94 & 100 & 100 & 83 & 83 \\
\hline
\end{tabular}

Notes: ${ }^{a}$ See Table $2.1 ;{ }^{b} 95 \%$ HPDIs in squared brackets, standard deviation in parenthesis, constant not reported. 
TABLE 3.2 Parameter point estimates for short-run output response obtained from 10,000 Gibbs-Sampler iterations and "burn in" phase of 500 iterations (pooled sample 1991-2006)

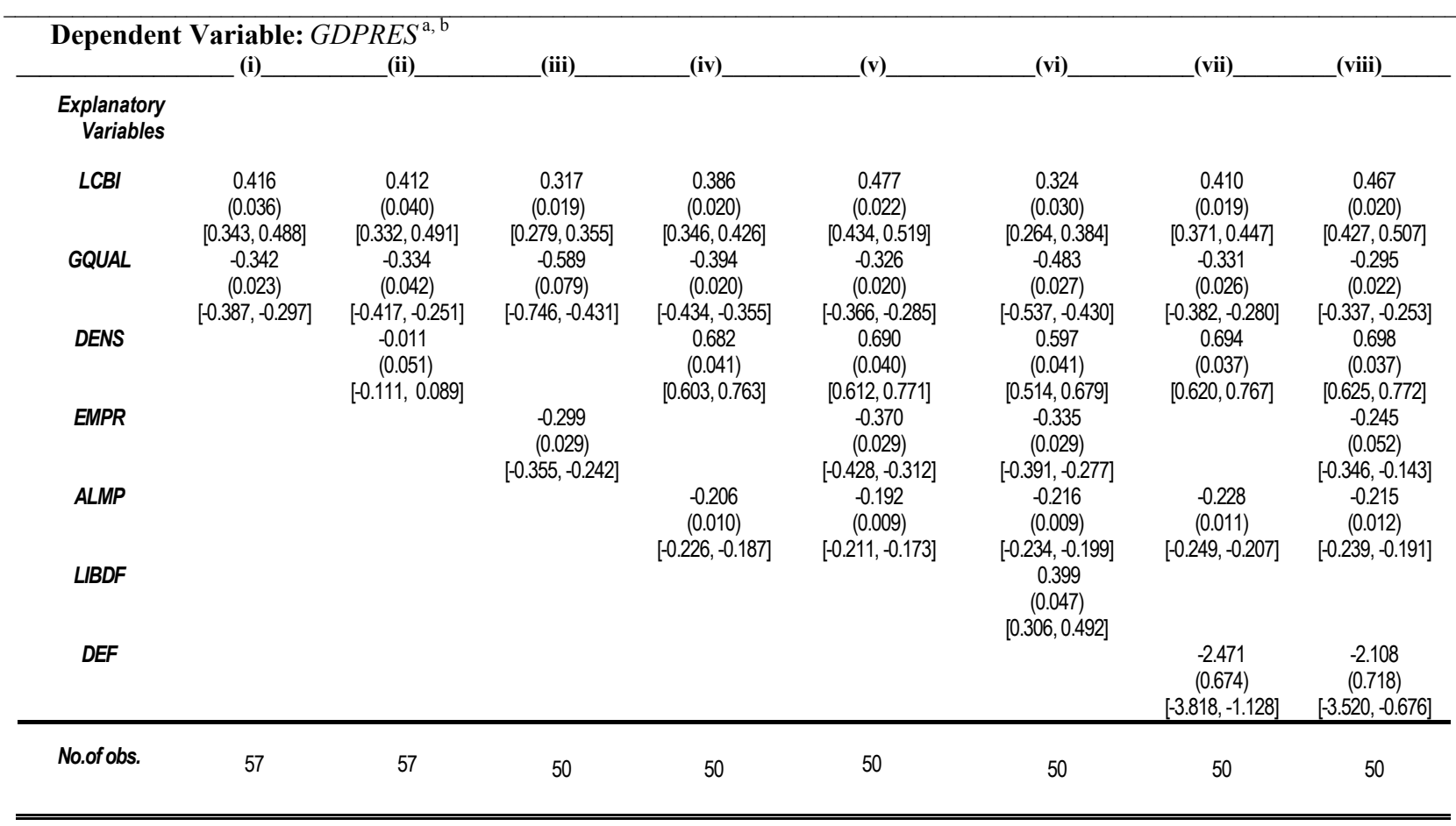

Notes: ${ }^{\mathrm{a}}$ See Table $3.1 ;{ }^{\mathrm{b}}$ 95\% HPDIs in squared brackets, standard deviation in parenthesis. 


\section{GRAPHS 2.1 Graphical representation of parameter convergence - Inflation}
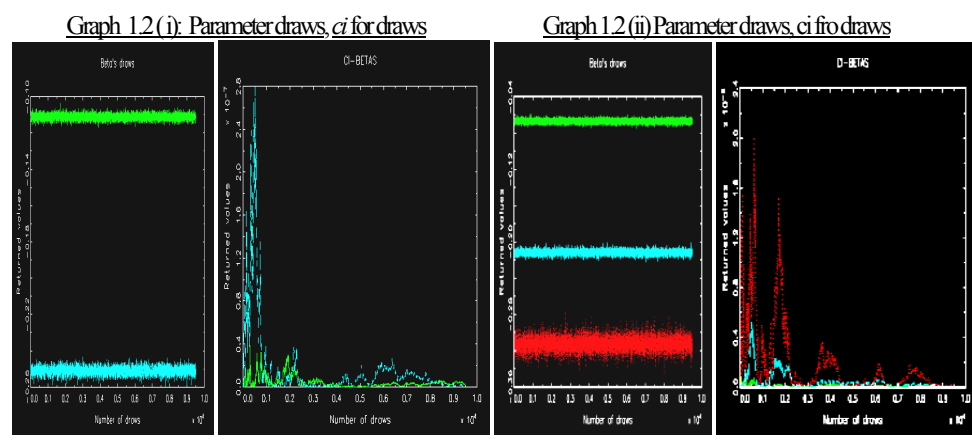

Graph 1.2(iii): Parameterdraws, ci fordraws

Graph 1.2(iv): Parameterdraws, ci fordraws
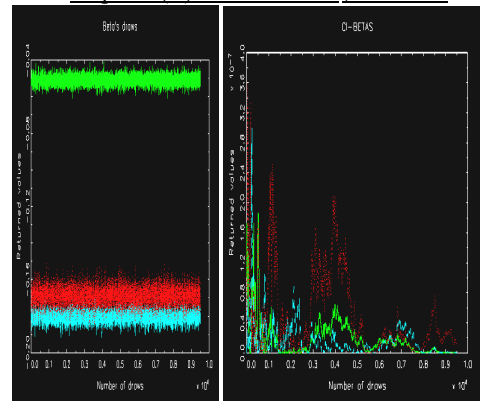

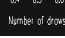

Graph 1.2(v): Parameterdraws, $c$ i fordraws

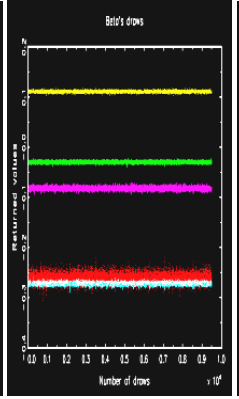

Antor did dow

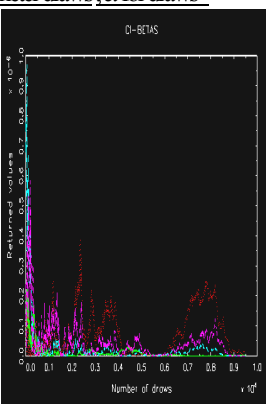

Graph 1.2(viii): Parameterdraws, $c$ i fordraws
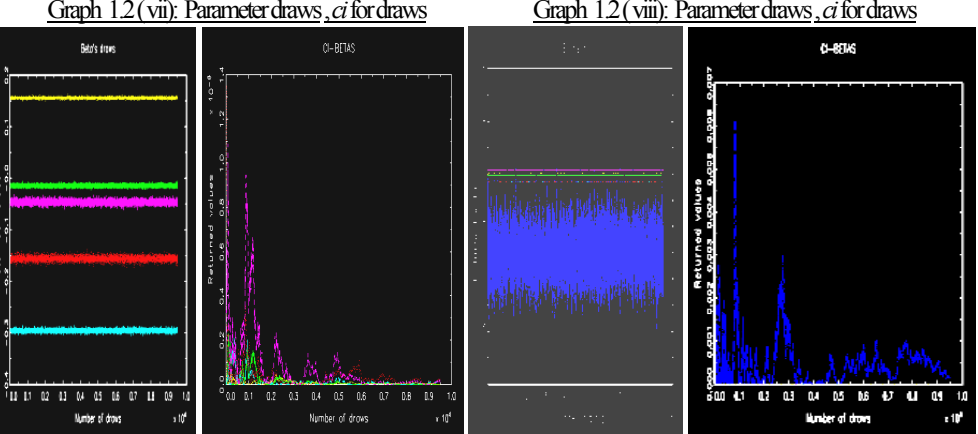

Graph 1.2(ix): Parameterdraws, $c i$ fordraws
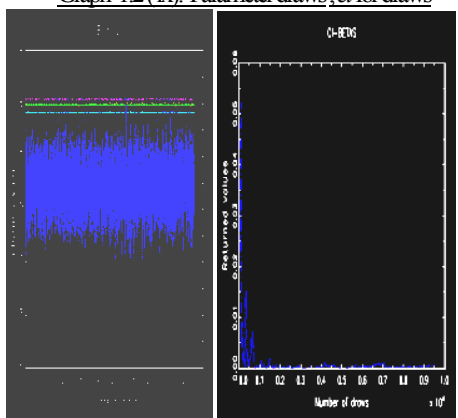

Graph 1.2(vi): Parameterdraws, $c i$ fordraws
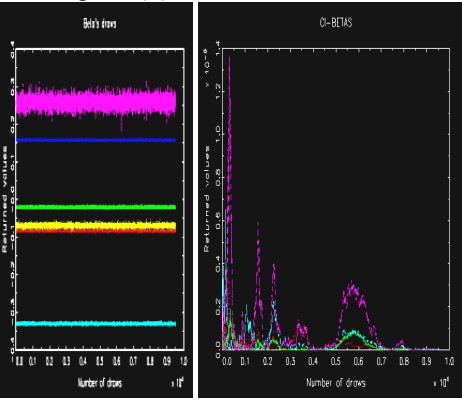

thiserition

Graph 1.2(x): Parameterdraws, $c$ i fordraws

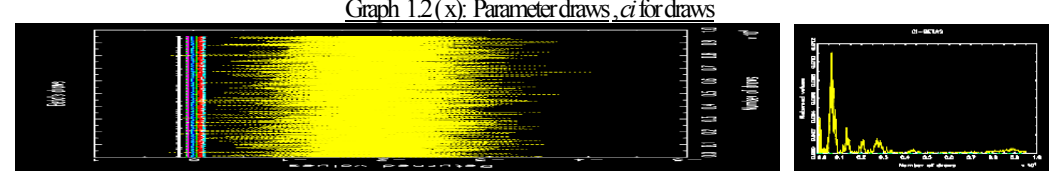

Graph 1.2(xi): Parameterdraws, ci fordraws

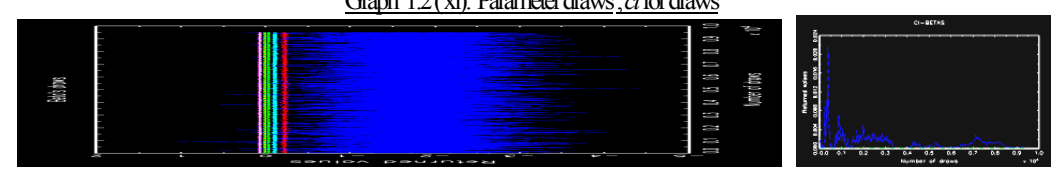

Graph 1.2(xii): Parameterdraws, ci fordraws

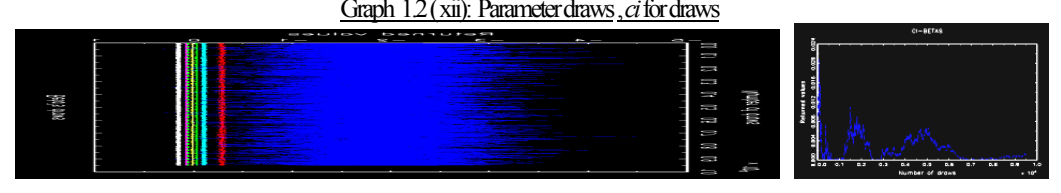


GRAPHS 2.2 Graphical representation of parameter convergence-Employment growth

Graph 2.2 (i): Parameter draws, $c i$ for draws
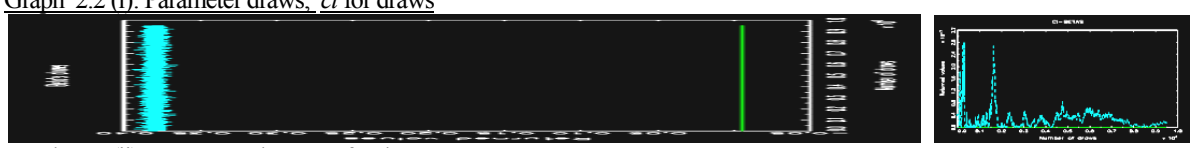

Graph 2.2 (ii): Parameter draws, $c$ i for draws
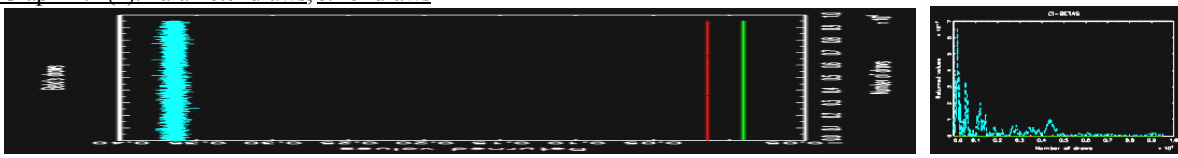

Graph 2.2 (iii): Parameter draws, $c$ i for draws

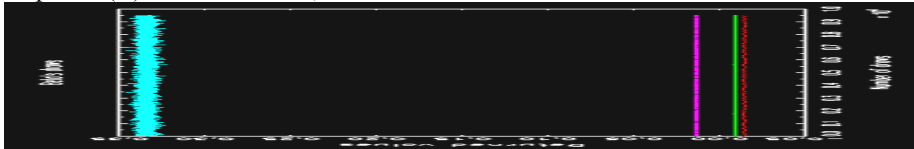

Graph 2.2 (iv): Parameter draws, $c i$ for draws
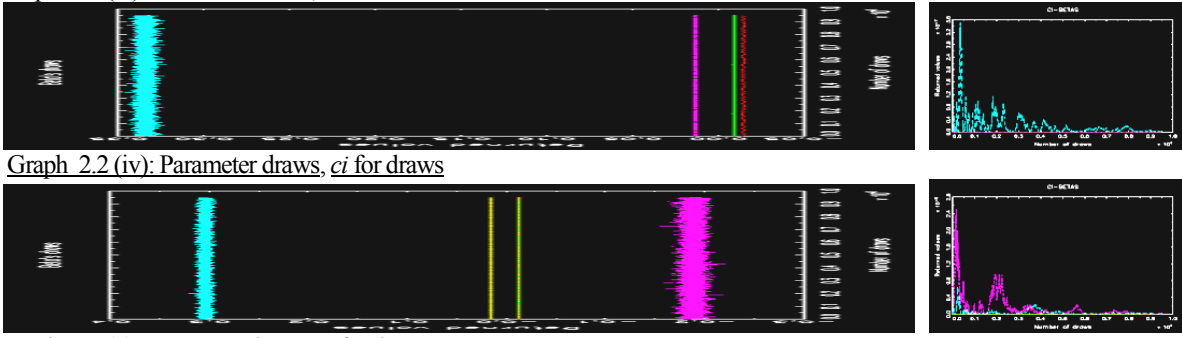

Graph 2.2. (v): Parameter draws, $c i$ for draws
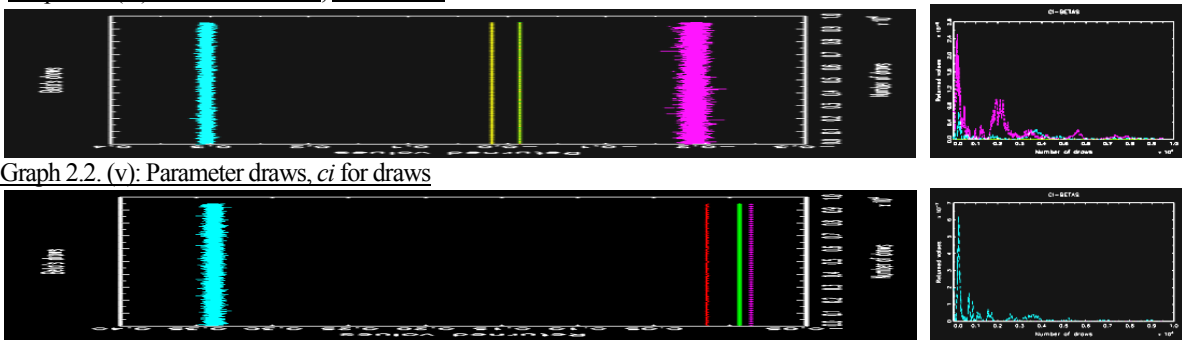

Graph 2.2. (vi): Parameter draws, $c i$ for draws
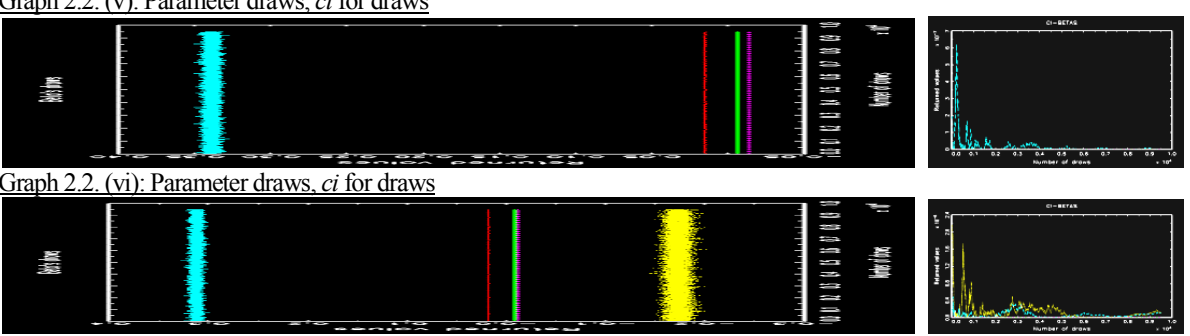

Graph 2.2 (vii): Parameter draws, $c i$ for draws
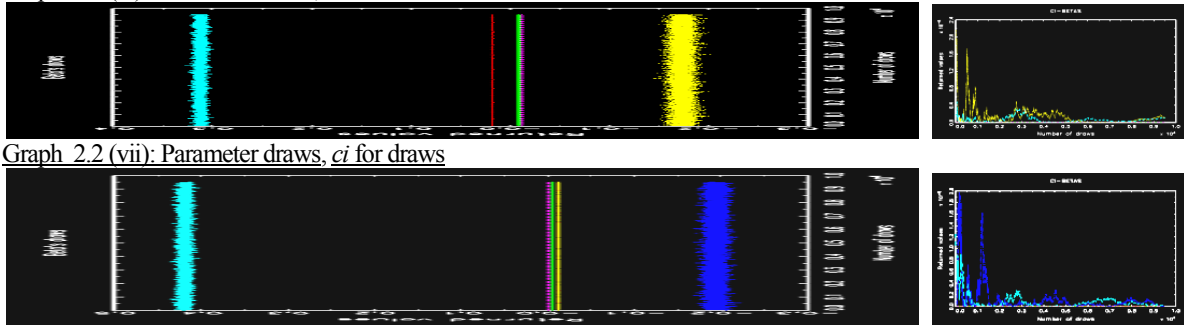

Graph 2.2 (viii): Parameter draws, $c$ i for draws
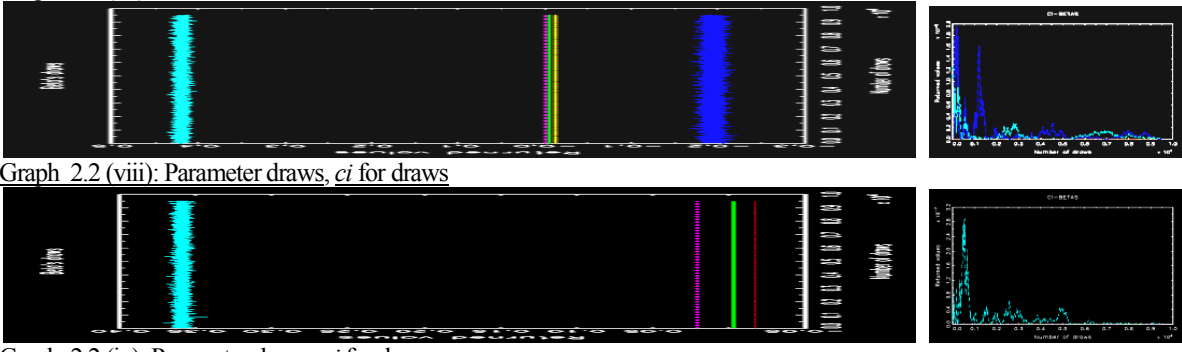

Graph 2.2 (ix): Parameter draws, $c i$ for draws
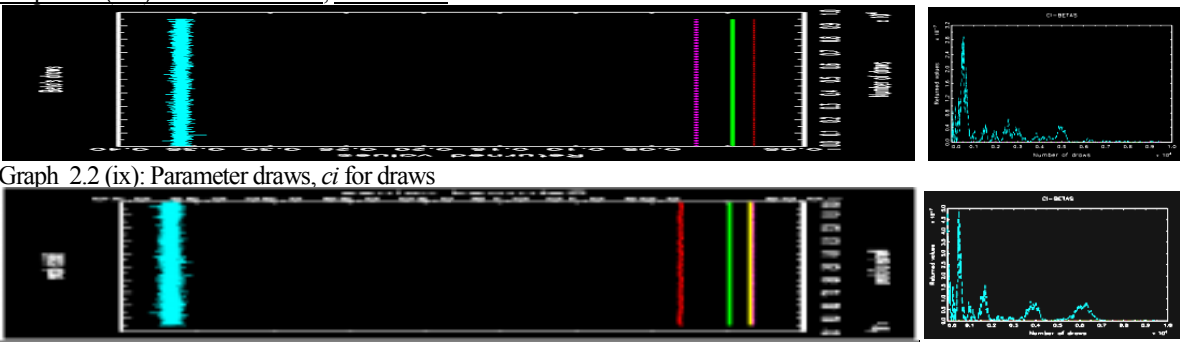

Graph 2.2 (x): Parameter draws, $c i$ for draws

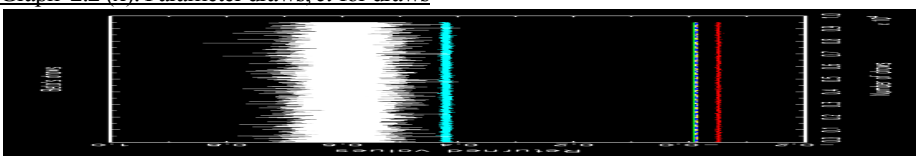

Graph 2.2 (xi): Parameter draws, $c$ i for draws
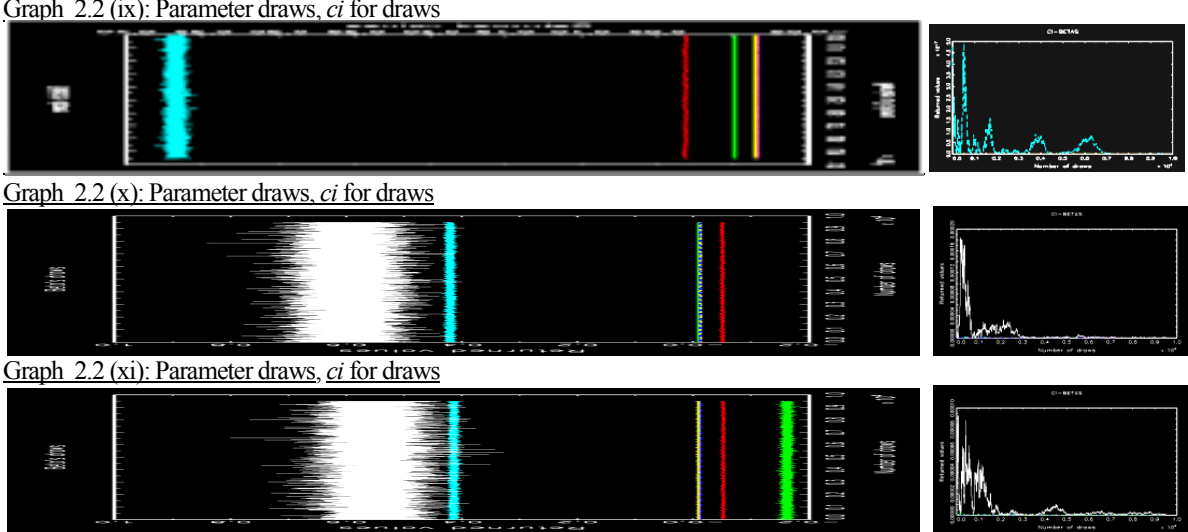


\section{GRAPHS 3.2 Graphical representation of parameter convergence-Short-run output response}
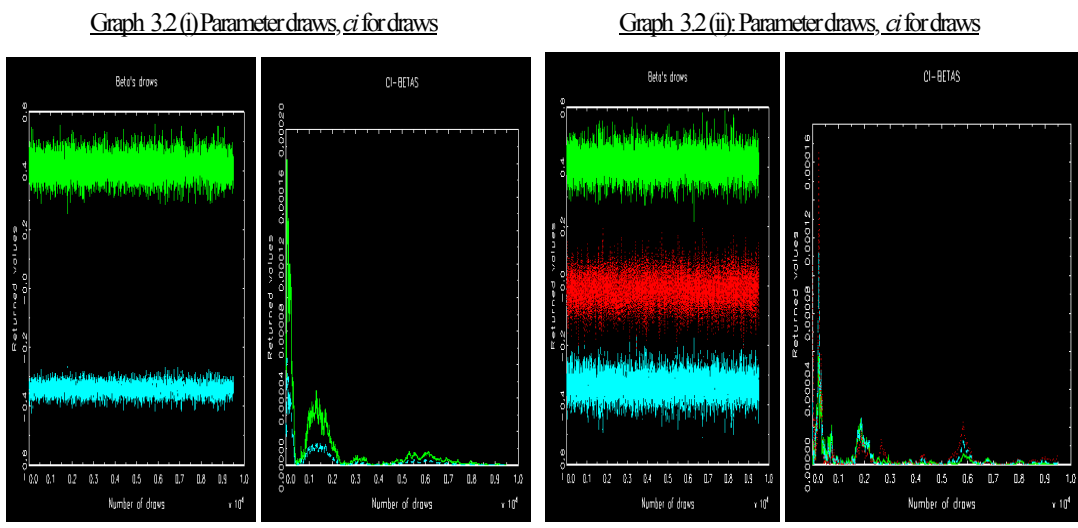

Graph 3.2(iii): Parameterdraws, $\underline{\text { i fordraws }}$

Graph 32 (iv): Parameterdraws, $c$ i fordraws

Graph 32(v)Parameterdraws, $c$ i fordraws
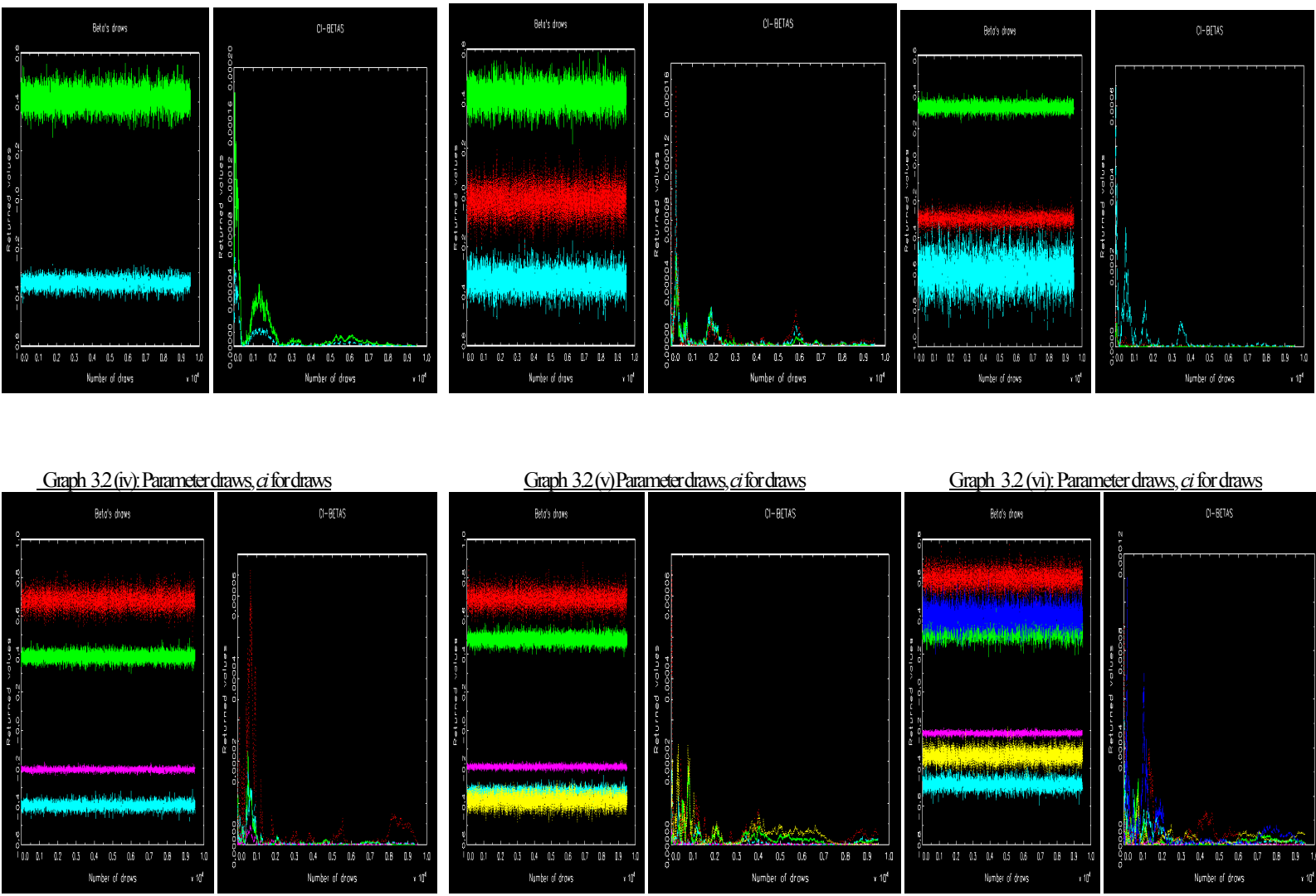

Graph 3.2(vi): Parameter draws, $c$ i fordraws

Graph 3.2 (vii): Parameter draws, $c i$ for draws
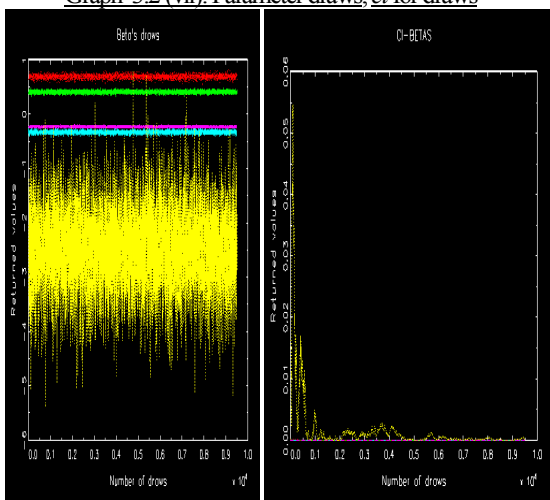

Graph 3.2 (viii): Parameter draws, $c i$ for draws
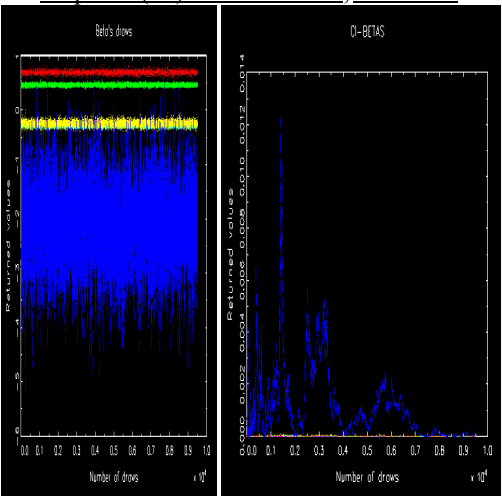